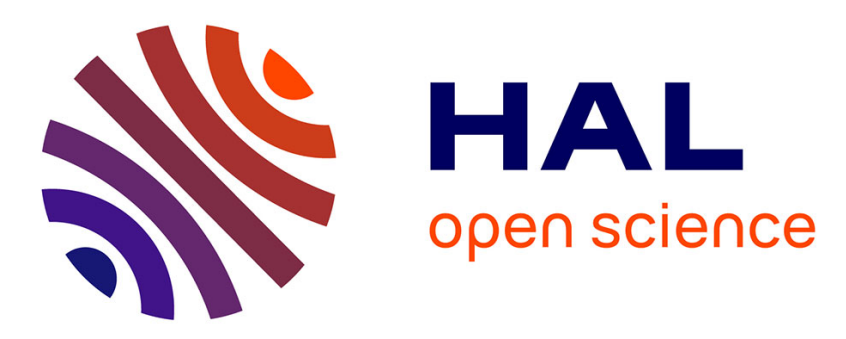

\title{
Pricing-based practices, conflicts and performance in franchising
}

Brinja Meiseberg, Rozenn Perrigot

\section{To cite this version:}

Brinja Meiseberg, Rozenn Perrigot. Pricing-based practices, conflicts and performance in franchising. European Management Journal, 2020, 38 (6), pp.939-955. 10.1016/j.emj.2020.04.004 . hal-02638435

\section{HAL Id: hal-02638435 \\ https://hal-univ-rennes1.archives-ouvertes.fr/hal-02638435}

Submitted on 28 May 2020

HAL is a multi-disciplinary open access archive for the deposit and dissemination of scientific research documents, whether they are published or not. The documents may come from teaching and research institutions in France or abroad, or from public or private research centers.
L'archive ouverte pluridisciplinaire HAL, est destinée au dépôt et à la diffusion de documents scientifiques de niveau recherche, publiés ou non, émanant des établissements d'enseignement et de recherche français ou étrangers, des laboratoires publics ou privés. 


\section{PRICING-BASED PRACTICES, CONFLICTS AND PERFORMANCE IN FRANCHISING}

Brinja Meiseberg, Ph.D. (Corresponding Author)

Westfälische Wilhelms-Universität Münster

Institute of Strategic Management

Leonardo-Campus 18

48149 Münster

Germany

Tel: +49-251-8331959

Fax: +49-251-8338333

E-mail: meiseberg@ism.uni-muenster.de

Rozenn Perrigot, Ph.D. ${ }^{1}$

Graduate School of Management (IGR-IAE Rennes)

CREM UMR CNRS 6211

University of Rennes 1

11 rue Jean Macé - CS 70803

35708 Rennes Cedex 7

France

E-mail: rozenn.perrigot@univ-rennes1.fr

\footnotetext{
${ }^{1}$ Rozenn Perrigot thanks the French National Research Agency (references: FRANBLE - ANR-12-BSH1-001101) as well as the Center in Franchising, Retail \& Service Chains for their valuable support.
} 


\title{
PRICING-BASED PRACTICES, CONFLICTS, AND PERFORMANCE IN FRANCHISING
}

\begin{abstract}
Pricing management is complex in hybrid organizations like franchising, as much of the raison d'être of franchising is built upon maintaining chain uniformity. However, franchisees and franchisors may have very different views on what the optimal prices are at a given unit. The aim of our research is thus to assess how resale pricing decisions are made and implemented in franchised chains and what the business consequences are. Our research question is then "Which pricing-based practices reduce conflicts between franchisors and franchisees and so enhance performance?" Based on a questionnaire-based survey of 406 franchisees in the largest European franchise market, France, the results of our analyses show that resale pricing in franchised chains is of crucial importance not only vis-à-vis customers, but also vis-à-vis franchisees, particularly concerning their satisfaction, store performance, and intention to acquire additional stores. On the franchisor part, pricing is essential in terms of brand performance and brand name value. Regarding the franchisor-franchisee relationship, pricing is crucial in terms of the occurrence of conflicts.
\end{abstract}

\section{KEYWORDS}

Pricing, resale price management, franchising, market performance, relational governance, cooperation 


\section{INTRODUCTION}

Resale pricing is an important criterion for customers when choosing to buy a product and/or a service. The price tagged on a product often involves very specific calculations to determine the right price that will be accepted by customers; it is sometimes the origin of conflicts between franchisors and franchisees. As an article in MSA Worldwide explains:

"In 2009, Burger King became embroiled in a "price setting" squabble with its National Franchisee Association over its decision to require franchisees to sell its double cheeseburger for no more than $\$ 1.00$. [...] Burger King claimed that the issue of maximum pricing had previously been litigated, and that the court found in that case that they had the right to require adherence to a value menu with maximum prices by its franchisees. [...] The NFA claimed that Burger King had set the price at $\$ 1.00$ and by doing so had caused its members to lose money on the individual transaction. [...] Whether the basic business strategy of consistency includes a franchisor's ability to control its promotional message, including a maximum price, is the issue that the Burger King litigation decided. Burger King did win - the court dismissed all counts. [... $]^{p 1}$

This example, as well as that of McDonald's in certain European courntries where there were similar concerns about McDonald's franchising terms and conditions, including prices set for products sold at franchise and consumers being charged more at franchised restaurants than at McDonald's own restaurants, ${ }^{2}$ shows that resale pricing is a hot topic in the specific case of franchising - with consequences for brand/customer relationships as well as

\footnotetext{
${ }^{1} \mathrm{https}: / / \mathrm{www} . \mathrm{msaw}$ orldwide.com/blog/franchisor_setting_prices_tinkering_again_with_the_rules_of_business/ ${ }^{2}$ https://www.businessinsider.com/r-mcdonalds-faces-complaints-in-europe-over-franchise-terms-2017-4? IR=T
} 
franchisor/franchisee relationships.

Franchising is "a contractual arrangement between two independent firms, whereby the franchisee pays the franchisor for the right to sell the franchisor's product [and/or services] and/or the right to use his trademark at a given place and for a certain period of time [...]. [T]he relationship between franchisor and franchisees 'includes not only the product, service, and trademark, but the entire business format itself - a marketing strategy and plan, operating manuals and standards, quality control, and continuing two-way communication [...]" (Lafontaine, 1992, p. 264).

Much of the raison d'être of franchising is built upon maintaining chain uniformity (Kaufmann \& Eroglu, 1999), so franchisors who strive for uniformity of products and services, store decor and experiences they offer to customers aim to offer uniformity of prices to all customers. In fact, consumers may expect price uniformity and react negatively towards a chain if they find "too much" price variation (Lafontaine, 1995). Yet, franchisees and franchisors may have different views on what the optimal prices are at a given store (Kalnins, 2003; Kosová, Lafontaine, \& Perrigot, 2013; Lafontaine \& Slade, 1997). Franchisors have chain-wide considerations when contemplating optimal prices. Franchisees, in contrast, predominantly take into account their local market conditions (Lafontaine, 1999). Moreover, since the royalties the franchisor receives depend on store sales, franchisors are interested in lower prices and high sales (Vroom \& Gimeno, 2007), whereas franchisees are predominantly concerned with their profits, not sales. Finally, as corporate stores obviously do not pay royalties, franchisees may choose higher prices than the prices the franchisor sets in corporate stores to compensate for income that franchisees feel gets "lost" by making the royalty payments.

To ensure chain uniformity, franchise contracts specify detailed sets of requirements that 
franchisees have to follow. Nonetheless, franchisees - as independent entrepreneurs - can set up their own resale prices on the products and/or services they sell in their local stores. As the Commission Regulation (EU) No 330/2010 states, franchisors are forbidden to impose resale prices on their franchisees, though they may suggest a recommended or maximum price (Basset \& Perrigot, 2015). The Competition Act 1998 in the UK "generally allows a franchisor to recommend or set a maximum price for goods or services sold by its franchisees, provided this does not in practice constitute a fixed or minimum price." Similar rules apply to countries outside the European market such as the Australian market where it is acceptable for franchisors to provide recommended resale prices to their franchisees and set maximum resale prices. In the US, antitrust regulations are more stringent regarding minimum rather than maximum resale prices (Blair and Lafontaine, 2005).

However, franchisors often seek ways to influence franchisees' resale prices (Ater \& Rigbi, 2013). They use explicit practices (e.g., recommendations, training on resale pricing strategies) and/or implicit practices that correspond to "disguised" practices that in fact are a way for franchisors to indirectly impose their prices (e.g., pre-labeled products, cash register programs) to encourage their franchisees to apply the recommended prices. Moreover, relational governance (norms of behavior safeguarding potential conflicts) in the chain affects how well integrating franchisor and franchisee resale pricing goals works out, which in turn affects business outcomes.

The aim of our research is thus to assess how resale pricing decisions are made and implemented in franchised chains and what the business consequences are. Our research question is "Which pricing-based practices reduce conflicts between franchisors and franchisees and so enhance performance?"

In this perspective, our empirical study examines franchising practices in France, the leading 
market for franchising in Europe and the third largest in the world, with 2,004 franchisors, 75,193 franchised stores, 62.01 billion euros of total sales and about 700,000 jobs (French Franchise Federation, 2019). A questionnaire-based survey was conducted with franchisees in retailing and services. The final sample included 406 respondents. Our results show that resale pricing in franchised chains is of crucial importance not only vis-à-vis customers, but also vis-à-vis franchisees, particularly concerning their satisfaction, store performance, and plans to acquire additional stores. Resale pricing is important for the franchisors, as well, in terms of brand performance and brand name value, and for the franchisor-franchisee relationship, in terms of occurrence of conflicts.

Our paper contributes to literature and practice. On the one hand, the literature on resale pricing in franchising being scarce (Basset \& Perrigot, 2015; Perrigot \& Basset, 2018; Perrigot et al., 2016; Stassen, 2017), our research on the pricing-based practices reducing franchisor/franchisee conflicts and enhancing the franchising performance fills this gap. We provide evidence of how relational governance can help with balancing interests in the context of resale pricing management. Moreover, contrary to the focus of previous literature (e.g., Basset \& Perrigot, 2015), our findings show that franchisee autonomy in resale pricing has no impact on conflicts, nor on performance. Finally, contrary to many legal or qualitative papers, the results of our questionnaire-based survey can be generalized.

On the other hand, regarding managerial implications, our results show that franchisors could change how they communicate recommended resale prices to their franchisees, such as using price lists or grids on an Intranet platform and having on-field consultants provide clear explanations. Additionally, franchisee allegiance and confidence in franchisor pricing have positive outcomes. In order to enhance this allegiance and confidence, franchisors could include sessions dealing with resale pricing as part of the initial and continuous 
training offered to franchisees. Having company-owned stores within the chain can be an indirect way to increase franchisee allegiance and confidence in franchisor pricing. Finally, granting franchisees autonomy in pricing has no significant effect. Even though franchisees are independent small business owners, often claiming their autonomy, they expect guidance from their franchisors, including recommendations on resale prices to be applied in their stores.

The paper is structured as follows. In section 2, we review the literature. Then, in section 3, we develop the research hypotheses on parameters that determine relationships between resale pricing and several outcomes linked to performance and conflicts. Section 4 describes the methodology. We present and discuss the results in sections 5 and 6 , respectively.

\section{LITERATURE REVIEW}

\subsection{Legal background}

In the U.S., the case of State Oil Company vs. Khan regarding imposing maximum resale price maintenance (RPM) was considered unlawful and in violation of $\S 1$ of the Sherman Act under the U.S. antitrust law, which refers to unreasonable restraints of trade "without elaborate inquiry as to the precise harm they have caused or the business excuse for their use," before the 1997 decision which determined that maximum RPM should be examined under the rule of reason standard (see Blair \& Lafontaine, 1999). On June 28, 2007, however, the Supreme Court issued its long-awaited decision in Leegin Creative Products, Inc. vs. PSKS, Inc. By a five-to-four margin, the Supreme Court overturned the condemnation of minimum RPM, opining that minimum RPM should instead be scrutinized under the rule of reason, the "traditional framework of analysis" under $\S 1$ of the Sherman Act. It requires the court to determine on a case-by-case basis whether the restraint in question "is one that promotes competition or one that suppresses competition" (Lockerby, 2007). 
Although the 1997 decision by the U.S. Supreme Court in State Oil Company v. Khan potentially opened the door for franchisor intervention in franchisees' resale prices, franchisors still find it difficult to directly intervene. Consistent with this view, Matthew Paull, McDonald's Corporation CFO, stated: "Our [corporate-owned restaurants] prices are probably, on average, 3 percent or 4 percent below our franchisees' prices, bear in mind that we are required by law [not to directly intervene]... and we never ever try to influence their [franchisees'] pricing."3

In the case of Europe, there are very few national laws that regulate the franchising sector (e.g., "Doubin Law" in France). However, the European Commission legislation applies. In particular, Commission Regulation (EU) No. 330/2010 of 20 April 2010 on the application of Article 101(3) of the Treaty on the Functioning of the European Union to categories of vertical agreements and concerted practices, and the Guidelines on Vertical Restraints 2010/C 130/01 that took effect on June 2010 for a period of twelve years (Perrigot \& Basset, 2015). The baseline is in accordance with article 4 a) of the 2010 Commission Regulation: franchise contracts cannot, directly or indirectly, restrain the ability of the franchisee to determine actual resale prices. According to this article 4 a), the franchisor can nonetheless "impose a maximum sale price or recommend a sale price, provided that they do not amount to a fixed or minimum sale price as a result of pressure from, or incentives offered by, any of the parties". The recommended resale price, or indicative price, is therefore a price provided for information purposes only. ${ }^{4}$

\footnotetext{
${ }^{3}$ Matthew Paull, McDonald's Corporation CFO at McDonald's Earnings Conference Call, 01/24/06.

${ }^{4}$ ECJ, 28 January 1986, Case 161/84.
} 
The Court of Justice of the European Community also found that franchise contracts can lawfully include a recommended resale price clause, "if the clauses that prejudice the ability of the franchisee to freely set its prices are restrictive of the competition, it is not the same when the franchisor provides the franchisees with indicative prices, provided that there are no joint practices between the franchisor and the franchisees or between the franchisees for the effective application of the prices." ${ }^{, 5}$ Like Community Law, domestic French Law recognizes the validity of the communication of indicative prices by the franchisor provided that the franchisor recognizes the franchisee right not to apply the recommended prices and to set their own resale prices.

Some research has taken such a legal perspective into account, focusing on the interplay of maximum sales price and anti-trust laws (Blair \& Esquibel, 1996; Blair \& Lafontaine, 2005; Perrigot \& Basset, 2015). For instance, a recommended price clause in franchise contracts cannot allow the franchisor to apply questionable practices, such as supplying pre-tagged products with printed barcodes and prices without any mention of the recommended prices. Even if franchisees are granted the possibility of modifying indicative prices, this ability is in practice limited by the fact that they usually manage a large number of items in their stores and that modifying the prices indicated on the tags would involve a great deal of work; the costs for franchisees could dissuade them from doing so (Perrigot \& Basset, 2015). Another questionable practice concerns when "the recommended sale price [is] pre-entered in the cash-registers most of the franchisees [are] equipped with and that [are] directly connected to the franchisor" (Perrigot \& Basset, 2015). Advertising campaigns and leaflets with the printed (recommended) resale prices, which force the franchisees to use these prices when they agree to take part in a campaign were also ruled unlawful in many cases (Perrigot \& Basset, 2015).

\footnotetext{
${ }^{5}$ ECJ, 28 January 1986, Case 161/84, §25.
} 


\subsection{Economic and managerial background}

Initially, Rubin (1978) argued that the franchise relationship is superior to the employment relationship as a solution to the agency problem of motivating store managers because franchising makes the franchisee the residual claimant of operations at the store (Michael, 2000). Standard economic theory suggests that the residual claimant status of an agent will induce greater effort, so in effect the franchise contract divides tasks and associated residual claims to create incentives that promote efficiency for both franchisor and franchisee (Michael, 2000; Rubin, 1978). Subsequently, different authors have stressed different aspects of these incentives, such as the division of revenue through royalties, the right to sell the store, or the payment of quasi-rents (Caves \& Murphy, 1976; Lafontaine, 1995, 1999; Michael, 2000). Despite these advantages of the franchised organizational form, the literature has also emphasized that the decentralized decision process in franchising decreases uniformity across stores.

Perhaps the best illustration of the tension between franchisees and franchisors concerns resale pricing (Ater \& Rigbi, 2013). Formally, franchisees set the prices at their local stores. In effect, franchisors, aware of the impact of prices on sales, royalties and chain image, seek ways to influence or impose these prices (Ater \& Rigbi, 2013). In trying to influence franchisees' resale pricing behavior, contracts obviously cannot cover every aspect of the franchisee's business, let alone future resale pricing (Kidwell, Nygaard, \& Silkoset, 2007; Shane, 1996; Vroom \& Gimeno, 2007). For instance, the duration of franchising contracts, sometimes up to twenty years, makes it impossible to consider each contingency at the time the contract is written. 
Under incomplete contracting (Gallini \& Lutz, 1992; Hendrikse \& Jiang, 2011; Maness, 1996), there are various theoretical arguments why franchisees might want to price their offering at a level different from the franchisor's preferred prices or from the prices the franchisor uses in their corporate stores. In franchised settings, a monopolist upstream sells an input to a downstream firm at a price above marginal cost (Lafontaine, 1995). According to the "double marginalization" principle, the downstream firm will want to choose a price that is higher, and a quantity that is lower, than the price and quantity that would maximize joint profits (Barron \& Umbeck, 1984; Lafontaine, 1995; Shepard, 1993).

Moreover, positive demand externalities might lead franchisees to choose higher downstream prices. Lowering prices in one location leads to an increase in demand at that location, but it also increases demand at other locations. The franchisee maximizing his profits will consider only the effect on his own sales (Barron \& Umbeck, 1984). Franchisors however, due to chain-wide considerations, would want franchisees to choose prices that stimulate demand chain-wide. Thus, franchisors would prefer that franchisees set a price below the one that maximizes the single store's profits. This would also imply that prices at company-owned stores should be lower than those in franchised stores (Lafontaine, 1995).

As far as negative demand externalities, i.e., downstream competition, are concerned, they could theoretically make franchisees pick prices also below the franchisor's optimal prices if free-riding leads franchisees to choose extremely low effort levels (Shepard, 1993) and if company managers's efforts are better monitored.

Through royalties, franchisors extract revenues as a percentage of franchisees' sales who, in turn, are less interested in maximizing sales than maximizing their profits. Hence, whereas franchisees would prefer higher prices, franchisors would prefer lower prices to increase franchisee sales volume while, given that corporate stores are profit centers for 
the franchisors, maintaining high prices there (Lafontaine, 1999).

In the existing literature, several researchers have assumed that resale prices are set at the franchisee level (Barron \& Umbeck, 1984; Blair \& Kaserman, 1982; Caves \& Murphy, 1976; Gallini \& Lutz, 1992; Gal'Or, 1991; Hadfield, 1991; Rubin, 1978; Shepard, 1993). Smith (1982) and Barron and Umbeck (1984) have found that regulations that impose more restrictions on the contractual arrangements upstream firms use leads to higher downstream prices.

Some other researchers have explored the differences between corporate and franchised chains, as far as maintaining a consistent position in the market in terms of price, quality, and advertising are concerned (Michael, 2002). Other authors have also looked at differences in terms of resale prices between stores in the catering and hospitality sectors (Kalnins, 2003; Kosová, Lafontaine, \& Perrigot, 2013; Lafontaine, 1995, 1999; Thomadsen, 2005). In general, the existing evidence, particularly in the fast food industry, shows that franchisees charge higher prices than corporate stores (Graddy, 1997; Kalnins, 2003; Lafontaine 1999; Lafontaine \& Slade, 1997). Results of a study on the hotel industry in Texas (Conlin, 2003; Vroom \& Gimeno, 2007), however, suggest that franchised hotels charge lower prices than corporate-owned hotels. Still, Kosová, Lafontaine and Perrigot (2013) have shown that there is no significant difference in resale prices between corporate and franchised hotels, once controlling for selection bias in the organizational form assigned to any particular hotel location.

Other scholars have looked at the use of advertising to coordinate and improve control over the prices charged by franchised stores using the example of McDonald's (Ater \& Rigbi, 2013). But so far, in franchising there is a lack of empirical research on resale pricing management and its effects on the performance of franchisees (unit performance, 
satisfaction), franchisors (brand performance, brand name value), and the entire system (overall conflict, conflict on pricing). These questions persist despite the high importance of resale pricing management at the operational level. That is the reason why we aim at answering the following research question "Which practices reduce conflicts between franchisors and franchisees and so enhance performance?"

\section{RESEARCH HYPOTHESES}

\subsection{Franchisor Perspective}

Scholars have explored the question of price-setting in franchising from an economic perspective (Blair \& Esquibel, 1996; Perrigot, Basset, \& Meiseberg, 2016). According to the resource-based view, firms' value appropriation may be explained by differences in the economic efficiency of the resources and knowledge controlled by firms, and firms with better resources create more value than competitors (Hallberg, 2018; Peteraf \& Barney, 2003). Then, if franchisors develop superior pricing knowledge over time, franchisor advice in terms of pricing management should benefit brand performance. This superior pricing knowledge refers to "organizational know-how", i.e., competences or capabilities of franchisors and their staff at the chain headquarters (Gillis et al., forthcoming) developed, for instance, through the operation of company-owned stores to acquire accurate knowledge, to the consideration of franchisee feedbacks via the on-field consultant or a specific committee to get a global overview, to the recruitment of pricing experts. Then, franchisees also would benefit from (voluntarily) adopting proven pricing schemes rather than working on a trial and error basis. Accordingly, direct pricing practices, that is the explicit recommendation of prices though different means such as the on-field consultant, grids, catalogs, etc., can help increase performance on the franchisor and franchisee level and decrease conflicts in the franchisor-franchisee relationship. 
H1: The franchisor's direct pricing practices (a) enhance franchisor- and franchisee-level business outcomes and (b) decrease the level of conflict present in the chain.

In theory, however, franchisors might find it uneconomical or complicated to set prices optimally for all locations (Lafontaine, 1995; 1999). That is, given that the franchisor's know-how on pricing is not "perfect" for all franchised units, e.g., as markets are diverse, encouraging franchisees to cooperate in setting the recommended prices could help find an adequate balance of centralized and local know-how, thereby increasing brand and unit performance (Lafontaine \& Slade, 1996). Franchisees could be encouraged to give information to their franchisors to set up the best recommended prices depending on their local market and their direct knowledge on local competitors and local customers (Meiseberg, 2013). Franchisors would appreciate franchisee cooperation and there would be some intermediate level of control by the franchisor to set up the final recommended prices. Besides, if franchisees perceive that they can cooperate with their franchisors on the elaboration of the recommended prices, rather than being "forced" to apply the recommended prices without having given their inputs, the level of conflict in the franchisor-franchisee relationship should decrease.

\section{H2: The franchisor/franchisee cooperation in pricing practices (a) enhances franchisor-and franchisee-level business outcomes and (b) decreases the level of conflict present in the chain.}

Moreover, given legal constraints concerning price set-up, franchisors might look for alternative mechanisms to control franchisees' prices (Blair \& Kaserman, 1978, 1980; Dixit, 1983; Gallini \& Winter, 1983; Lafontaine, 1999; Mathewson \& Winter, 1983, 1984). By indirect pricing tactics, and more explicitly said, disguised practices such as pre- 
recording resale prices in franchisee cash registers and making it so difficult for the latter to modify them, or supplying franchisees with pre-labeled tags indicating the prices on the items and also making it difficult to modify them, franchisors can impose prices on their franchisees. Franchisees, in turn, may perceive indirect pricing as being highly "unfair", which could reduce their motivation to comply, and would increase the level of conflict and decrease performance for all.

\author{
H3: The franchisor's indirect pricing practices (a) decrease franchisor-and \\ franchisee-level business outcomes and (b) increase the level of conflict present in \\ the chain.
}

\title{
3.2 Franchisee Perspective
}

Knowledge sharing has become a major research theme in different management disciplines (Boer, Berends, \& van Baalen, 2011). Constant, Sproull, and Kiesler (1994) argue that knowledge transmission and adoption is affected by rational self-interest and the social and organizational context in which relationships are embedded, with trusting, long-term relationships often working as a means to ease knowledge flow among parties. Then, given that the franchisor has developed superior market knowledge on pricing practices over time, franchisee allegiance in terms of pricing management should benefit brand and unit performance. Besides, franchisees should value the ability to adopt such practices that work out, thereby decreasing conflicts in the franchisor-franchisee relationship.

H4: The franchisees' allegiance to the franchisor's pricing practices (a) enhances franchisor-and franchisee-level business outcomes and (b) decreases the level of conflict present in the chain. 
Likewise, higher confidence in the franchisor's pricing practices should drive franchisees to follow tested pricing procedures. Consequently, unit performance should increase. Similarly, uniformity and thus brand value should be strengthened, and conflict between partners would decrease.

H5: The franchisees' confidence in the franchisor's pricing practices (a) enhances franchisor-and franchisee-level business outcomes and (b) decreases the level of conflict present in the chain.

Autonomy can be understood as the extent to which a party, here a franchisee, is unconstrained to independently make decisions and to take action (Jensen \& Meckling, 1992; Strutton, Pelton, \& Lumpkin, 1995). Granting franchisee autonomy despite inconsistencies in objectives between franchisor and franchisees usually carries the risk of franchisee freeriding (Dant \& Gundlach, 1999; Michael, 2002, 2000, 1999; Pizanti \& Lerner, 2003). In pricing management, consumers likely lose trust in the brand if prices vary "too much" or advertised prices are hardly found in practice. Franchisors granting high levels of price authority rather than trying to "influence" franchisees may particularly grant this authority due to a lack of own pricing know-how, resulting in a trial-and-error process borne by the franchisees. Then franchisees' perception of being used as "guinea pigs" may decrease efforts and performance and increase conflict.

H6: The franchisees' autonomy in pricing practices (a) decreases franchisor and franchisee level business outcomes and (b) increases the level of conflict present in the chain. 


\subsection{System-Level-Perspective: Relational Governance}

Partners involved in economic exchange develop relationships over time: Trust, shared norms, and routines - the core aspects of relational governance - emerge via repeated exchange, and help to coordinate activity, incentivize investment in relationship-specific resources, and encourage the development and transfer of valuable knowledge (Chatterji, Cunningham, \& Joseph, 2019; Kotabe, Martin, \& Domoto, 2003; Poppo \& Zenger, 2002). Accordingly, we define relational governance as norms of behavior and unwritten codes of conduct which safeguard exchanges against potential conflicts (Cochet, Dormann, \& Ehrmann, 2008). Norms, in turn, are defined as expectations of behavior shared by dyadic partners (Heide \& John, 1992). They emerge from the social embeddedness of a contractual relationship (Granovetter, 1985; Jones, Hesterly, \& Borgatti, 1997; Macneil, 1980, Ring \& Van de Ven, 1994), conditioned by the prospect of realizing a higher transaction value in the future than would be possible without such norms (Baker, Gibbons, \& Murphy, 2002; Cochet, Dormann, \& Ehrmann, 2008). Communication as "the formal as well as informal sharing of meaningful and timely information between firms" (Anderson \& Narus, 1990) represents the "glue" that holds partners together, and entails a firm having the know-how and skills to convey relevant information to the partners in a timely, accurate, and complete manner (Agostini, 2016; Heide \& John, 1990; Lambe, Spekmann, \& Hunt, 2000; Schreiner, Kale, \& Corsten, 2009). Koza and Dant (2007) argue that "[i]nformation should be viewed as an investment that one channel member makes in another [...], and communication provides the means of transfer of knowledge between channel member firms. Therefore, $[\ldots]$ members [...] strive to put in place integrating mechanisms that enable effective interaction, hence allowing the greatest chance for each to succeed [...]. Communication is a strategic integrating mechanism". Mohr, Fisher, and Nevin (1996) point out communication as the most important element to successful interfirm exchange. They suggest that communication, 
viewed as relationship-building cooperative attitudes, creates an atmosphere of performanceenhancing mutual support. Accordingly, communication between franchisor and franchisees should enhance performance and decrease conflict.

\section{H7: Mutual communication on pricing practices (a) enhances franchisor and franchisee level business outcomes and $(b)$ decreases the level of conflict present in the chain.}

Apart from communication, the governance conceptualization studied here contains two other elements: the efforts for harmonization of conflict, defined as the extent to which a franchisee and a franchisor find mutually satisfying, nonopportunistic solutions to conflicts (Mohr \& Spekman, 1994); and the prevalence of mutual understanding, also acting as a mechanism against the risk of opportunistic action (Bradach \& Eccles, 1989; Granovetter, 1985; Zaheer \& Venkatraman, 1995; Zaheer, McEvily, \& Perrone, 1998;). Efforts to increase harmony in dealings as well as mutual understanding should also represent a relationship feature that enhances relationship outcomes in terms of improved performance and reduced conflict.

H8: Mutual harmonization efforts concerning attitudes towards pricing practices (a) enhances franchisor and franchisee level business outcomes and (b) decreases the level of conflict present in the chain.

H9: Mutual understanding of each other's interests concerning pricing practices (a) enhances franchisor and franchisee level business outcomes and (b) decreases the level of conflict present in the chain. 


\section{METHODOLOGY}

To answer the research question and test the research hypotheses, we studied franchising in France. France is the leading franchising market in Europe and the third in the world, having 2,004 franchisors, 75,193 franchised stores, 62.01 billion euros of total sales, and about 700,000 jobs (French Franchise Federation, 2019). A questionnaire-based survey was conducted with franchisees in retailing and services.

As suggested by Barthélemy $(2008,2011)$, we used a four-stage process to design the questionnaire. First, we prepared a first version of the questionnaire, mainly using constructs whose reliability had been demonstrated in previous research (Atuahene-Gima \& Ko, 2001), adapting them where appropriate to the franchising and pricing context. Second, we asked for feedback from colleagues and experts in franchising, and took into consideration their suggestions. Third, we pretested the questionnaire on a dozen franchisees in the retail and service sectors. Fourth, we took into account their feedbacks to get the final version of the questionnaire. Overall, this four-stage process allowed revisions in the contructs and ensured the face and content validity of the survey (Hughes \& Morgan, 2007).

The final sample included 406 respondents. The sampling frame for this empirical study was drawn from a population of franchisees whose contact information was available on franchisors' websites. 7,138 franchisees were on the final list. Emails with a cover letter and the online survey were sent out to the final list of franchisees in early 2014 using the QuestionPro platform. After three follow-up emails, we received 406 questionnaires fullyfilled. For a description of the sample franchisees, see Table 1.

All measures - the latent constructs and the control metrics - were based on measures developed in previous research. At the franchisor level, we measured direct pricing adapted from Meek et al. (2011), franchisor/franchisee cooperation in pricing practices based on 
Cochet et al. (2008), and indirect pricing using information gained through interviewing franchisees in the pre-study. At the franchisee level, we measured allegiance to pricing practices adapted from Williams (2007), confidence in pricing practices from based on Cochet et al. (2008), and autonomy in pricing using Blut et al. (2011). At the system-level, we measured communication on pricing practices adapted from Chiou, Hsieh, and Yang (2004), harmonization efforts concerning pricing practices from Cochet et al. (2008), and mutual understanding concerning interests in pricing practices from Tikoo (2005). As far as outcomes were concerned, at the franchisor level, we measured chain performance adapted from Blut et al. (2011), brand name value from Hussain et al. (2013); at the franchisee-level, store performance from Mignonac et al. (2015), satisfaction from Davies et al. (2011), and intention to acquire additional stores from Mignonac et al. (2015); at the system level, overall conflict from Davies et al. (2011) and conflict on pricing practices also from Davies et al. (2011). The list of items, scale sources, and reliability statistics for the latent constructs can be found in Appendix 3.

We tested for nonresponse bias using two comparisons. First, we compared early and late respondents in terms of key study variables. Second, we also compared the sales volumes and the industry distribution pattern of those companies to whom the survey was sent with those that actually responded. Neither comparison revealed significant differences, indicating that nonresponse was not an issue. We also checked for common method bias using several procedural remedies (MacKenzie \& Podsakoff, 2012). We pretested the questionnaire on a dozen franchisees from retail and service sectors and took into account their feedback for the clarity of the questions. We ensured anonymity of the responses. We mainly used constructs whose reliability had been confirmed in previous research. We run the Harman one-factor test (Podsakoff et al., 2003), with all items from the constructs in our study included in a factor analysis. The results yielded eight factors which accounted for $63.2 \%$ of the total variance, 
with the first factor accounting for $23.5 \%$ of the variance. Therefore, the test yielded more than one factor and no one factor accounted for most of the variance (Rhee et al., 2010). Common method variance is then unlikely to be a major issue in this research and the measures can be considered as valid (Rhee et al., 2010; Stam \& Elfring, 2008). Hence, common method bias was not expected to be a serious problem.

To test our model based on the survey data, we used a structural equation modeling framework. Fornell and Larcker (1981) noted that any assessment of the structural model should be preceded by a rigorous evaluation of the measurement model that demonstrates satisfactory levels of validity and reliability. Construct measures should be unidimensional as well as reliable. Thus, before assessing any structural relationships, we evaluated the measurement model using confirmatory factor analysis (CFA) (Yiu \& Lau, 2008). We proceeded in line with An et al. (2019), Shen \& Tang (2018), Zhao et al. (2016), and Sanchez-Famoso, Maseda \& Iturralde (2014). All items showed high correlation coefficients concerning their respective latent construct (all coefficients were larger than 0.78 ). The suggested constructs were further supported by the comparative fit index (CFI > 0.97), Bentler and Bonett's normed fit index (NFI > 0.89), Tucker and Lewis's non-normed fit index (NNFI > 0.90), Bollen's incremental fit index (IFI > .94), and root mean square error of approximation (RMSEA < 0.05). Scale reliability was assessed by the computation of Cronbach's alpha and, as can be seen from Appendix 3, the lowest value for latent constructs is 0.615 . When factor analyzed, all factor loadings were found to be highly significant and there are no cross-loadings larger than 0.30, which indicates convergent validity (Bagozzi, Yi, \& Phillips, 1991; Homburg, Grozdanovic, \& Klarmann, 2007). Convergent validity was also assessed and the computation of average variance extracted (AVE; Fornell \& Larcker, 1981; see Appendix 3 for the observed AVE estimates, except one, all estimates are >0.50). 
Discriminant validity of the constructs was evaluated by comparing AVE with squares of inter-trait correlations (Fornell \& Larcker, 1981). Discriminant validity is demonstrated when the square of the correlations is less than the AVE or when the square root of the AVE is larger than the correlations. Our smallest square root of AVE is .70 which exceeds all of the correlation coefficients except one (see Table 1).

\section{RESULTS}

\subsection{Descriptive Results}

As initial results, the survey data revealed that pricing decisions in the chains under investigation were in fact a central issue and prone to induce franchisor-franchisee conflicts (see Appendix 2). From the franchisee's perspective, pricing decisions are taken on the basis of a large variety of relevant criteria (Appendix 2, Fig. 2 and 3). The franchisor's role in pricing is perceived as being the role of an advisor, yet almost as much, as an instructor that is "giving orders" to franchisees on how to set prices (Fig. 4). Franchisors' information on pricing strategies is foremost given through franchisee coaching, intra- and extranet connections, and regional meetings, whereas little is laid out in the franchise contract (Fig. 5). Price "directions" by the franchisor are commonly given as recommendations, yet there are also pricing schedules, price lists, maximum prices, and price ranges supplied (Fig. 6). "Indirect pricing", i.e., implicit and disguised methods for influencing prices, are franchisor provision of all display tools, IT management systems, catalogs containing prices distributed to consumers, price statements on the website, and cash register systems, and there are even cases where price changes by a franchisee are billed to this franchisee (Fig. 7). Concerning the intensity of cooperation between both parties, franchisees show lower cooperation on pricing than in other aspects of the franchisor's business model (e.g., adopting franchisor policies concerning product assortments, work processes, and marketing) (Fig. 8). As regards 
deviations from standards set by the franchisor, franchisees deviate from these standards more often in terms of pricing than in other aspects of the franchisor's business model (Fig. 9). In essence, the diverging motivations of franchisors and franchisees in the area of pricing become rather obvious.

\subsection{Test of the Research Hypotheses}

Moving on with the empirical examination of the survey data, Tables $2 a$ and $2 b$ show correlations for all measures employed. Table 3 displays means and standard deviations. Table 4 presents results. Model fit statistics show satisfactory model fit (CFIs $\geq 0.94$, NFIs $\geq$ 0.92, IFIs $\geq 0.94$, RMSEA 0.08; see Table 4).

With respect to the franchisor-level variables, we find that franchisors' use of direct pricing is significantly and positively related to brand performance and brand name value (both 5\%level), as well as to unit performance (1\%-level) and franchisee satisfaction $(0.1 \%$-level). Further, direct pricing reduces the level of overall franchisor-franchisee conflict (5\%-level). These findings offer support for H1. In contrast, indirect pricing is negatively related to brand performance (1\%-level) and franchisee satisfaction (0.1\%-level), and increases overall and pricing conflicts, in line with $\mathrm{H} 3$. H2 goes unsupported: Franchisor/franchisee cooperation in pricing is related little to outcomes (only at the 10\%-level, it reduces unit performance).

As regards franchisee-level variables, franchisee allegiance to franchisor pricing is positively related to brand performance (5\%-level) and brand name value (10\%-level). Further, the linkage to franchisee intention to acquire additional units (10\%-level) and satisfaction is positive (5\%-level; potentially, more satisfied franchisees are more willing to adhere to franchisor standards anyway). Moreover, franchisee allegiance decreases conflict on pricing (1\%-level), offering support to H4. In addition, high franchisee confidence in franchisor pricing concurs with high unit performance (10\%-level), satisfaction (5\%-level), and 
intention (10\%-level) to acquire additional units (possibly, as franchisees are also more likely to believe in the franchisor, be satisfied, and expand if the performance of their unit is good), which partly supports H5. H6 is not supported: Autonomy does not affect outcomes.

Turning to system-level variables, mutual harmonization efforts concerning pricing enhance brand performance (5\%-level) and franchisee satisfaction ( $0.1 \%$-level) and decrease overall and pricing conflicts (both $0.1 \%$-level; as predicted by H8). The presence of mutual understanding of partners' interests particularly increases franchisee satisfaction $(0.1 \%$-level $)$ as predicted by $\mathrm{H} 7$, although there is little effect on other outcome variables (only a 10\%level effect on brand name value). Mutual communication on pricing practices does not affect performance much, yet it is positively and significantly related to conflict (5\%-level), contrary to H9 (possibly, more intense communication decreases the reluctance to reveal preferences, thereby increasing dispute over matters).

Concerning the control variables, chain size is positively related to brand performance, brand name value, unit performance, and intention to acquire additional units. Likewise, chain age is positively connected to brand name value and franchisee satisfaction, yet decreases the intention to acquire additional units, overall, and pricing conflicts. Multi-unit ownership enhances all business outcomes and decreases pricing conflicts. Provision of exclusive territory has no effect on outcomes; environmental uncertainty is harmful to unit performance, but has no other effect on outcomes, either. ${ }^{6}$

[Tables 1-4]

\footnotetext{
${ }^{6}$ We also controlled for sectors (retailing and services, not presented here due to nonsignificant results).
} 


\subsection{Summary of Findings}

Resale pricing in franchised chains is of crucial importance not only vis-à-vis customers, but also vis-à-vis franchisees, particularly concerning their satisfaction, store performance, and intention to acquire additional stores. On the franchisor part, pricing is important in terms of brand performance and brand name value. Regarding the franchisor-franchisee relationship, pricing is particularly important in terms of the occurrence of conflicts. The results of our empirical study allow to answer the research question "Which pricing-based practices reduce conflicts between franchisors and franchisees and so enhance performance?" In more detail, they show the following characteristics.

First, several practices reduce the conflicts between franchisors and franchisees and/or enhance the franchising performance, as measured through different outputs. Franchisor use of direct pricing significantly and positively impacts brand performance, brand name value, store performance, and franchisee satisfaction, as well as significantly and negatively impacts overall conflict. In the same vein, franchisee allegiance to franchisor pricing significantly and positively impacts brand performance, brand name value, franchisee satisfaction, and intention to acquire additional stores, as well as significantly and negatively impacts conflict on pricing. Franchisee confidence in franchisor pricing significantly and positively impacts store performance, franchisee satisfaction, and intention to acquire additional stores, as well as significantly and negatively impacts overall conflict. Mutual harmonization efforts concerning pricing practices significantly and positively impacts brand performance and franchisee satisfaction, as well as significantly and negatively impacts overall conflict and conflict on pricing. Mutual understanding of interests concerning pricing practices significantly and positively impacts brand name value and franchisee satisfaction. 
Second, conversely, a few specific practices increase the conflicts between franchisors and franchisees and/or decrease the franchising performance, as measured through different outputs. Franchisor use of indirect pricing significantly and negatively impacts brand performance and franchisee satisfaction, as well as significantly and positively impacts overall conflict and conflict on pricing. Franchisor/franchisee cooperation in pricing significantly and negatively impacts store performance. Mutual communication on pricing practices significantly and positively impacts conflict on pricing.

Third, franchisee autonomy in pricing does not have any significant impact on any of the outputs.

\section{DISCUSSION}

\subsection{Contributions to the Literature}

This research contributes to the literature on franchising and, more specifically, to the stream dealing with resale pricing in franchising (e.g., Ater \& Rigbi, 2015; Basset \& Perrigot, 2015; Perrigot \& Basset, 2018; Perrigot et al., 2016). We build on the literature by demonstrating the impact of franchisors' practices (e.g., franchisor use of direct and indirect pricing), franchisees' attitudes towards these practices (e.g., franchisee allegiance and confidence in franchisor pricing), and relational governance (e.g., mutual harmonization efforts concerning pricing practices) on several outputs, including brand performance and brand name value; store performance, franchisee satisfaction, and intention to acquire additional stores; and overall conflict and conflict on pricing. In particular, scholars have discussed concerns with franchisors' and franchisees' free-riding behavior and how this problem can be mitigated (Brickley 1999; Brickley \& Dark, 1987; Cochet, Dormann, \& Ehrmann, 2008; Klein \& Leffler, 1981; Lafontaine \& Shaw, 2005; Lafontaine \& Slade, 2007; Rubin, 1978). As a complement, we explore franchisee cooperative attitudes concerning franchisors' resale 
pricing preferences. Moreover, research has addressed various aspects of relational governance in terms of alleviating organizational problems (e.g., Cochet, Dormann, \& Ehrmann, 2008). We provide evidence on effects of relational governance that can help with balancing interests in the context of resale pricing management.

More specifically, as far as franchisee autonomy is concerned, some papers have dealt with the legal aspects of resale pricing in franchising associated with franchisee autonomy in price-setting (e.g., Basset \& Perrigot, 2015). Our findings show that franchisee autonomy in resale pricing, contrary to what one could expect, has no impact on any of the outputs under investigation—neither on performance, nor on conflicts. López-Bayón \& López-Fernández (2016) had found that delegation of pricing decisions increased terminations of franchise contracts within chains. They explained that their "findings regarding pricing decisions support the claim that, within the antitrust legal framework, pricing policies should be controlled by the franchisor and thus integrated throughout the chain to some extent." (p. 1073).

Finally, many papers have focused on legal issues, with analyses of Court decisions (e.g., Basset and Perrigot, 2015) or qualitative-based studies (e.g., Perrigot \& Basset, 2018; Perrigot et al., 2016). Our empirical study relies on a quantitative approach based on 406 questionnaires from franchisees in the retail and service sector. Results are thus generalizable. Moreover, responding to Perrigot and Basset (2018), even though we collected data on franchisees only, we measured both franchisor and franchisee attitudes and practices, unlike many papers that looked at the one-sided franchisor approach (e.g., Perrigot \& Basset, 2018) or the one-sided franchisee approach (e.g., Perrigot et al., 2016). Our current study offers a broader understanding of resale pricing and its impact on franchising. 


\subsection{Managerial Implications}

Our research has several managerial implications. To start with, franchisors could adjust how they communicate recommended resale prices to their franchisees. They should rely more on direct pricing means instead of trying to "trick" franchisees into compliance with indirect pricing practices. The use of direct pricing communication increases brand performance and value, increases performance and satisfaction of the franchisees, and minimizes overall conflicts. Direct pricing could include providing recommended resale prices lists or grids on an Intranet platform, or sending them to the franchisees via email or through the post, or having on-field consultants explain pricing tactics to franchisees.

Our results show that brand performance, brand name value, and franchisee satisfaction increase particularly if franchisors inform franchisees about pricing strategies through meetings, and if franchisees perceive that the information given is comprehensive and precise. Unit performance, in turn, is high especially if pricing strategies are already laid out in the contract, or in the operations manual. Possibly, recorded information is easier to consult if needed; whereas the personal explanation of pricing tactics in meetings increases the franchisees' perception of being involved and seriously taken into account by the franchisor, thereby increasing satisfaction. Moreover, both kinds of conflict (price-related and overall) are reduced most if pricing strategy is explained by franchisee coaches, and if the information is perceived as comprehensive and precise. Further results on indirect pricing practices also show that brand performance and franchisee satisfaction are particularly negative if franchisors use marketing material that states fixed prices, which also increases conflicts the most.

We found that franchisee allegiance and confidence in franchisor pricing have various positive effects on the brand and the franchisee business and decrease conflict. Thus, to 
enhance allegiance and/or confidence, franchisors should include sessions dealing with resale pricing in the initial and the continuous training offered to franchisees. These sessions could be used to showcase how recommended prices are set up based on the competitive environment, customer price sensitivity, input costs, etc. Moreover, having company-owned stores in the chain can be a way to increase franchisor credibility as regards setting the "right" recommended prices, which can enhance franchisee allegiance and confidence in franchisor pricing as well.

According to our findings, granting franchisees autonomy in pricing has no significant effect, which may mean that imposing prices via indirect means and thereby triggering franchisee opposition and subsequent free-riding, may be a highly inferior strategy to proposing direct prices (as franchisees do not reject the latter). Even though franchisees are independent small business owners, often claiming their autonomy, they expect guidance from their franchisors, including recommendations of resale prices to be applied in their stores.

In sum, our results seem to imply that the best strategy is to have the franchisor leading the business in terms of pricing, while granting franchisees autonomy seems prone to create some trouble.

\subsection{Limitations and Tracks for Future Research}

Our research has some limitations that offer tracks for future research. First, even though we measure franchisor and franchisee attitudes and practices, we only measure them through the perspective of the franchisees. Conducting quantitative research on both franchisors and franchisees, administrating questionnaires to franchisors and their franchisees, and pairing the responses might offer additional insights. Second, our results from the questionnaire-based survey might be biased due to issues of endogeneity. For instance, there could be a reversed causality issue: franchisees who perform better economically will have more trust in 
franchisor resale pricing. Therefore, economic performance leads to confidence and vice versa. ${ }^{7}$ Similarly, although common method bias does not appear to be a serious limitation according to Harman's single factor test, we cannot rule it out completely. Future research on resale pricing strategies in franchising could also explore processes underlying franchisees' (non)compliance, study group dynamics in the chain, and determine effects of the interplay and evolution of local markets, chain characteristics, and franchisee selection in more detail.

\section{REFERENCES}

Agostini, L. (2016). Organizational and managerial activities in the development process of successful SME Marketing Networks. European Management Review, 13, 91-106.

An, N., Qiang, M., Wen, Q., Jiang, H., \& Xia, B. (2019). Contribution of project managers' capability to project ending performance under stressful conditions. European Management Journal, 37(2), 198-209.

Anderson, J. C., \& Narus, J. A. (1990). A model of distributor firm and manufacturer firm working partnerships, Journal of Marketing, 54(1), 42-58.

Ater, I., \& Rigbi, O. (2015). Price control and advertising in franchising chains. Strategic Management Journal, 36, 148-158

Atuahene-Gima, K., \& Ko, A. (2001). An empirical investigation of the effect of market orientation and entrepreneurship orientation alignment on product innovation. Organization Science, 12(1), 54-74.

Bagozzi, R. P., Yi, Y., \& Phillips, L. W. (1991). Assessing construct validity in organizational research. Administrative Science Quarterly, 36(3), 421-458.

Baker, G., Gibbons, R., \& Murphy, K. J. (2002). Relational contracts and the theory of the firm. Quarterly Journal of Economics, 117(1), 39-84.

Barron, J. M., \& Umbeck, J. R. (1984). The effects of different contractual arrangements: The case of retail gasoline markets. Journal of Law and Economics, 27(2), 313-328.

Barthélemy, J. (2008). Opportunism, knowledge, and the performance of franchise chains. Strategic Management Journal, 29, 1451-1463.

Barthélemy, J. (2011). Agency and institutional influences on franchising decisions. Journal of Business Venturing, 26(1), 93-103.

Basset, G., \& Perrigot, R. (2015). Franchisees' resale price policy facing legal, contractual and professional constraints: Insights from European and French perspectives. Research in

\footnotetext{
${ }^{7}$ We thank Reviewer 1 for having raised this issue.
} 
Law and Economics, 27, 119-142.

Blair, R. D., \& Esquibel, A. K. (1996). Maximum resale price restraints in franchising. Antitrust Law Journal, 65(1), 157-180.

Blair, R. D., \& Kaserman, D. L. (1978). Vertical integration, tying, and antitrust policy. American Economic Review, 68(3), 397-402.

Blair, R. D., \& Kaserman, D. L. (1980). Vertical control with variable proportions: Ownership integration and contractual equivalents. Southern Economic Journal, 46(4), 11181128.

Blair, R. D., \& Kaserman, D. L. (1982). Optimal franchising. Southern Economic Journal, 49(2), 494-505.

Blair, R. D., \& Lafontaine, F. (1999). Will Khan foster or hinder franchising? An economic analysis of maximum resale price maintenance. Journal of Public Policy in Marketing, 18(1), $25-36$.

Blair, R. D., \& Lafontaine, F. (2005). The economics of franchising. Cambridge, MA: Cambridge University Press.

Blut, M., Backhaus, C., Heussler, T., Woisetschläger, D., Evanschitzky, H., \& Ahlert, D. (2011). What to expect after the honeymoon: Testing a lifecycle theory of franchise relationships. Journal of Retailing, 87(3), 306-319.

Boer, N. I., Berends, H., \& van Baalen, P. (2011). Relational models for knowledge sharing behavior. European Management Journal, 29(2), 85-97.

Bradach, J. L., \& Eccles, R. G. (1989). Price, authority, and trust: From ideal types to plural forms. Annual Review of Sociology, 15, 97-118.

Brickley, J. A. (1999). Incentive conflicts and contractual restraints: Evidence from franchising. Journal of Law and Economics, 42(2), 745-774.

Brickley J. A., \& Dark, F. H. (1987). The choice of organizational form the case of franchising. Journal of Financial Economics, 18(2), 401-420.

Caves, R. E., \& Murphy, W. F. (1976). Franchising, firms, markets, and intangible assets. Southern Economic Journal, 42(4), 572-586.

Chatterji, A. K., Cunningham, C. M., \& Joseph, J. E. (2019). The limits of relational governance: Sales force strategies in the U.S. medical device industry. Strategic Management Journal, 40(1), 55-78.

Cochet, O., Dormann, J., \& Ehrmann, T. (2008). Capitalizing on franchisee autonomy, Relational forms of governance as controls in idiosyncratic franchise dyads. Journal of Small Business Management, 46(1), 50-72.

Chiou, J. S., Hsieh, C. H., \& Yang, C. H. (2004). The effect of franchisors' communication, service assistance, and competitive advantage on franchisees' intentions to remain in the franchise system. Journal of Small Business Management, 42(1), 19-36. 
Conlin, M. (2003). The effect of franchising on competition: An empirical analysis. Journal of Advertising, 24, 25-40.

Constant, D., Sproull, L., \& Kiesler, S. (1994). The kindness of strangers: The usefulness of electronic weak ties for technical advice. Organization Science, 7, 119-135.

Dant, R. P., \& Gundlach, G. T. (1999). The challenge of autonomy and dependence in franchised channels of distribution. Journal of Business Venturing, 14(1), 35-67.

Davies, M. A. P., Lassar, W., Manolis, C., Prince, M., \& Winsor, R. D. (2011). A model of trust and compliance in franchise relationships. Journal of Business Venturing, 26(3), 321340.

Dixit, A. (1983). Vertical integration in a monopolistically competitive industry. International Journal of Industrial Organization, 1(1), 63-78.

Fornell, C., \& Larcker, D. F. (1981). Structural equation models with unobservable variables and measurement error. Journal of Marketing Research, 18(3), 382-388.

French Franchise Federation. Les chiffres-clés en France. (2015). http://www.franchisefff.com/franchise/chiffres-cles/les-chiffres-cles-en-france.html Accessed 13 January 2017.

Gallini, N. T., \& Lutz, N. A. (1992). Dual distribution and royalty fees in franchising. Journal of Law, Economics, and Organization, 8(3), 471-501.

Gallini, N. T., \& Winter, R. A. (1983). On vertical control in monopolistic competition. International Journal of Industrial Organization, 1(3), 275-286.

Gal'Or, E. (1991). Optimal franchising in oligopolistic markets with uncertain demand. International Journal of Industrial Organization, 9(3), 343-364.

Gillis, W.E., Combs, J.G. and Yin, X. (forthcoming). Franchise management capabilities and franchisor performance under alternative franchise ownership strategies. Journal of Business Venturing, DOI: 10.1016/j.jbusvent.2018.09.004.

Graddy, K. (1997). Do fast-food chains price discriminate on the race and income characteristics of an area?. Journal of Business and Economic Statistics, 15(4), 391-401.

Granovetter, M. (1985). Economic action and social structure: The problem of embeddedness. American Journal of Sociology, 91(3), 481-510.

Hadfield, G. K. (1991). Credible spatial preemption through franchising. RAND Journal of Economics, 22(4), 531-543.

Hallberg, N. L. (201). Managing value appropriation in buyer-supplier relationships: The role of commercial decision resources. European Management Journal, 36(1), 125-134.

Heide, J. B., \& John, G. (1990). Alliances in industrial purchasing: The determinants of joint action in buyer-supplier relationships. Journal of Marketing Research, 27(1), 24-36.

Heide, J. B., \& John, G. (1992). Do norms matter in marketing relationships? Journal of Marketing, 56(2), 32-44. 
Hendrikse, G., \& Jiang, T. (2011). An incomplete contracting model of dual distribution in franchising. Journal of Retailing, 87(3), 332-344.

Homburg, C., Grozdanovic, M., \& Klarmann, M. (2007). Responsiveness to customers and competitors: The role of affective and cognitive organizational systems. Journal of Marketing, 71(3), 18-38.

Hughes, M. \& Morgan, R. (2007). Deconstructing the relationship between entrepreneurial orientation and business performance at the embryonic stage of firm growth. Industrial Marketing Management, 36(5), 651-661.

Hussain, D., Perrigot, R., Mignonac, K., El Akremi, A., \& Herrbach, O. (2013). Determinants of multi-unit franchising: An organizational economics framework. Managerial and Decision Economics, 34(5), 161-169.

Jensen, M. C., \& Meckling, W. H. (1992). Specific and general knowledge and organizational structure. Journal of Applied Corporate Finance, 8(2), 4-18.

Jones, C., Hesterly, W. S., \& Borgatti, S. P. (1997). A general theory of network governance: Exchange conditions and social mechanisms. Academy of Management Review, 22(4), 911945.

Kalnins, A. (2003). Hamburger prices and spatial econometrics. Journal of Economics and Management Strategy, 12(4), 591-616.

Kaufmann, P., \& Eroglu, S. (1999). Standardization and adaptation in business format franchising. Journal of Business Venturing, 14(1), 69-85.

Kidwell, R. E., Nygaard, A., \& Silkoset, R. (2007). Antecedents and effects of free riding in the franchisor-franchisee relationship. Journal of Business Venturing, 22(4), 522-544.

Klein, B., \& Leffler, K. B. (1981). The role of market forces in assuring contractual performance. Journal of Political Economy, 89(4), 615-641.

Kosová, R., Lafontaine, F., \& Perrigot R. (2013). Organizational form and performance: Evidence from the hotel industry. Review of Economics and Statistics, 95(4), 1303-1323.

Kotabe, M., Martin, X., \& Domoto, H. (2003). Gaining from vertical partnerships:

Knowledge transfer, relationship duration, and supplier performance improvement in the U.S. and Japanese automotive industries. Strategic Management Journal, 24(4), 293-316.

Koza, K. L., \& Dant, R. P. (2007). Effects of relationship climate, control mechanism, and communications on conflict resolution behavior and performance outcomes. Journal of Retailing, 83(3), 279-296.

Lafontaine, F. (1992). Agency theory and franchising: Some empirical results. Rand Journal of Economics, 23(2), 263-283.

Lafontaine, F. (1995). Pricing decision in franchised chains: A look at the restaurant and fastfood industry. Working paper 5247, National Bureau of Economic Research, Cambridge, MA. 
Lafontaine, F. (1999). Franchising versus corporate ownership: The effect on price dispersion. Journal of Business Venturing, 14(1), 17-34.

Lafontaine, F., \& Shaw, K. L. (2005). Targeting managerial control: Evidence from franchising. RAND Journal of Economics, 36(1), 131-150.

Lafontaine, F., \& Slade, M. E. (1996). Retail contracting and costly monitoring: Theory and evidence. European Economic Review, 40(3), 923-932.

Lafontaine, F., \& Slade, M. E. (1997). Retail contracting: Theory and practice. Journal of Industrial Economics, 45(1), 1-25.

Lafontaine, F., \& Slade, M. E. (2007). Vertical integration and firm boundaries: The evidence. Journal of Economic Literature, 45(3), 629-685.

Lambe, C. J., Spekman, R. E., \& Hunt, S. D. (2000). Interimistic relational exchange: Conceptualization and propositional development. Journal of the Academy of Marketing Science, 28(2), 212-225.

Lockerby, M. J. (2007). Franchising after Leegin: A license to fix prices. Franchise Law Journal, 27, 112-118.

López-Bayón, S., \& López-Fernández, B. (2016). Partner empowerment and relationship failure in franchising. Journal of Small Business Management, 54(4), 1059-1079.

Macneil, I. R. (1980). Economic analysis of contractual relations: Its shortfalls and the need for a rich classificatory apparatus. Northwestern University Law Review, 75, 1018-1063.

MacKenzie, S.B., \& Podsakoff, P.M. (2012). Common method bias in marketing: Causes, mechanisms, and procedural remedies. Journal of Retailing, 88(4), 542-555.

Maness, R. (1996). Incomplete contracts and the choice between vertical integration and franchising. Journal of Economic Behavior \& Organization, 31(1), 101-116.

Mathewson, G. F., \& Winter, R. A. (1983). Vertical integration by contractual restraints in spatial markets. Journal of Business, 56(4), 497-517.

Mathewson, G. F., \& Winter, R. A. (1984). An economic theory of vertical restraints. RAND Journal of Economics, 15(1), 27-38.

Meek, W. R., Davis-Sramek, B., Baucus, M. S., \& Germain, R. N. (2011). Commitment in franchising: The role of collaborative communication and a franchisee's propensity to leave. Entrepreneurship Theory and Practice, 35(3), 559-581.

Meiseberg, B. (2013). The prevalence and performance impact of synergies in the plural form. Managerial \& Decision Economics, 34(3-5), 140-160.

Michael, S. C. (1999). The elasticity of franchising. Small Business Economics, 12(4), 313320.

Michael, S. C. (2000). The effect of organizational form on quality: The case of franchising. Journal of Economic Behavior and Organization, 43(3), 295-318. 
Michael, S. C. (2002). Can a franchise chain coordinate? Journal of Business Venturing, 17(4), 325-341.

Mignonac, K., Vandenberghe, C., Perrigot, R., El Akremi, A., \& Herrbach, O. (2015). A multi-study investigation of outcomes of franchisees' affective commitment to their franchise organization. Entrepreneurship Theory and Practice, 39 (3), 461-488.

Mohr, J., Fisher, R. J., \& Nevin, J. R. (1996). Collaborative communication in interfirm relationships: Moderating effects of integration and control. Journal of Marketing, 60(3), $103-115$.

Mohr, J., \& Spekman, R. (1994). Characteristics of partnership success: Partnership attributes, communication behavior, and conflict resolution techniques. Strategic Management Journal, 15(2), 135-152.

Perrigot, R., \& Basset, G. (2015). The Impact of European legislation on franchising: A focus on know-how, e-commerce and resale prices. In J. Windsperger, G. Cliquet, T. Ehrmann, \& G. Hendrikse (Eds.), Interfirm Networks (pp. 149-170). Heidelberg: Springer-Verlag.

Perrigot, R., \& Basset, G. (2018). Resale pricing in franchised stores: A franchisor perspective. Journal of Retailing and Consumer Services, 43, 209-217.

Perrigot, R., Basset, G., \& Meiseberg, B. (2016). Resale prices in franchising: Insights from franchisee perspectives. Journal of Product and Brand Management, 25(7), 663-675.

Peteraf, M. A., \& Barney, J. B. (2003). Unraveling the resource-based tangle. Managerial and Decision Economics, 24, 309-323.

Pizanti, I., \& Lerner, M. (2003). Examining control and autonomy in the franchisorfranchisee relationship. International Small Business Journal, 21(2), 131-159.

Podsakoff, P. M., MacKenzie, S. B., Lee, J. Y., \& Podsakoff, N. P. (2003). Common method biases in behavioral research: A critical review of the literature and recommended remedies. Journal of Applied Psychology, 88(5), 879-903.

Poppo, L., \& Zenger, T. (2002). Do formal contracts and relational governance function as substitutes or complements? Strategic Management Journal, 23(8), 707-725.

Rhee, J., Park, T., \& Lee D.H. (2010). Drivers of innovativeness and performance for innovative SMEs in South Korea: Mediation of learning orientation. Technovation, 30(1), $65-75$.

Ring, P. S., \& Van de Ven, A. H. (1994). Developmental processes of cooperative interorganizational relationships. Academy of Management Review, 19(1), 90-118.

Rubin, P. H. (1978). The theory of the firm and the structure of the franchise contract. Journal of Law and Economics, 21(1), 223-233.

Sanchez-Famoso, V., Maseda, A., \& Iturralde, T. (2014). The role of internal social capital in organisational innovation. An empirical study of family firms. European Management Journal, 32(6), 950-962. 
Schreiner, M., Kale, P., \& Corsten, D. (2009). What really is alliance management capability and how does it impact alliance outcomes and success? Strategic Management Journal, 30(13), 1395-1419.

Shane, S. A. (1996). Hybrid organizational arrangements and their implications for firm growth and survival: A study of new franchisors. Academy of Management Journal, 39(1), 216-234.

Shen, J., \& Tang, C. (2018). How does training improve customer service quality? The roles of transfer of training and job satisfaction. European Management Journal, 36(6), 708-716.

Shepard, A. (1993). Contractual form, retail price, and asset characteristics in gasoline retailing. RAND Journal of Economics, 24(1), 58-77.

Smith, R. L. (1982). Franchise regulation: An economic analysis of state restrictions on automobile distribution. Journal of Law and Economics, 25(1), 125-157.

Stam, W., \& Elfring, T. (2008). Entrepreneurial orientation and new venture performance: The moderating role of intra- and extra-industry social capital. Academy of Management Journal, 51(1), 97-111.

Stassen, R. (2017). Resale price maintenance in franchising: market coverage, companyowned stores, and retailer dependence, in Hoy, F., Perrigot, R., and Terry, A. (Eds), Handbook of Research on Franchising (pp. 249-272). Edward Elgar Publishing,

Strutton, D., Pelton, L. E., \& Lumpkin, J. R. (1995). Psychological climate in franchising system channels and franchisor-franchisee solidarity. Journal of Business Research, 34(2), 81-91.

Thomadsen, R. (2005). The effect of ownership structure on prices in geographically differentiated industries. RAND Journal of Economics, 36(4), 908-929.

Tikoo, S. (2005). Franchisor use of influence and conflict in a business format franchise system. International Journal of Retail and Distribution Management, 33(5), 329-342.

Vroom, G., \& Gimeno, J. (2007). Ownership form, managerial incentives, and the intensity of rivalry. Academy of Management Journal, 50(4), 901-922.

Williams, C. (2007). Transfer in context: Replication and adaptation in knowledge transfer relationships. Strategic Management Journal, 28(9), 867-889.

Yiu, D. W., \& Lau, C. M. (2008). Corporate entrepreneurship as resource capital configuration in emerging market firms. Entrepreneurship Theory and Practice, 32(1), 3757.

Zaheer, A., McEvily, B., \& Perrone, V. (1998). Does trust matter? Exploring the effects of interorganizational and interpersonal trust on performance. Organization Science, 9(2), 141159.

Zaheer, A., \& Venkatraman, N. (1995). Relational governance as an interorganizational strategy: An empirical test of the role of trust in economic exchange. Strategic Management 
Journal, 16(5), 373-392.

Zhao, X., Shang, Y., Lin, J., Tan, J., Li, H. \& Liu, T. (2016). Leader's relational power: Concept, measurement and validation. European Management Journal, 34(5), 517-529. 


\section{Appendix 1}

\section{Table 1: Sample description}

\begin{tabular}{|c|c|c|}
\hline & Variable & Value (in round figures) \\
\hline (1) $\mathrm{C}$ & Gender $(1-$ male, 0 - female $)$ & $73 \%$ \\
\hline \multicolumn{3}{|c|}{ (2) Age Categories } \\
\hline & $<20 \mathrm{yrs}$ & $3 \%$ \\
\hline & 20-30 & $17 \%$ \\
\hline & $31-40$ & $18 \%$ \\
\hline & $41-50$ & $33 \%$ \\
\hline & $51-60$ & $16 \%$ \\
\hline & $>60 \mathrm{yrs}$ & $12 \%$ \\
\hline \multicolumn{3}{|c|}{ (3) Unit Ownership } \\
\hline & Single-Unit Franchisees & $79 \%$ \\
\hline & Multi-Unit Franchisees & $18 \%$ \\
\hline & Several Brands Franchisees & $3 \%$ \\
\hline (4) $\mathrm{F}$ & Retail Sector $(1-$ yes, $0-$ no $)$ & $41 \%$ \\
\hline (5) $\mathrm{A}$ & Average Contract Duration (in yrs) & 6.51 \\
\hline (6) $\mathrm{r}$ & Right to Exclusive Territory ( $1-$ yes, $0-$ no) & $78 \%$ \\
\hline (7) $\mathrm{A}$ & Average Time as a Franchisee of their Chain (in yrs) & 6.57 \\
\hline \multicolumn{3}{|c|}{ (8) Average number of people employed } \\
\hline & $<3$ & $24 \%$ \\
\hline & $3-7$ & $42 \%$ \\
\hline & $>7$ & $34 \%$ \\
\hline \multicolumn{3}{|c|}{ (9) Chain Age } \\
\hline & $<3 y r s$ & $2 \%$ \\
\hline & $3-5$ & $4 \%$ \\
\hline & 6-10 & $17 \%$ \\
\hline & $11-20$ & $28 \%$ \\
\hline & $>20 \mathrm{yrs}$ & $49 \%$ \\
\hline (10) & Average Number of Units per Chain & 178 \\
\hline (11) & Franchisees in Chains with an International Market Presence & $62 \%$ \\
\hline
\end{tabular}


Table 2a: Correlations

\begin{tabular}{|c|c|c|c|c|c|c|c|c|c|c|c|c|c|c|c|c|c|c|c|c|}
\hline \multirow[b]{2}{*}{ (1) Brand performance } & \multicolumn{2}{|l|}{1} & \multicolumn{2}{|l|}{2} & \multicolumn{2}{|l|}{3} & \multicolumn{2}{|l|}{4} & \multicolumn{2}{|l|}{5} & \multicolumn{2}{|l|}{6} & \multicolumn{2}{|l|}{7} & \multicolumn{2}{|l|}{8} & \multicolumn{2}{|l|}{9} & \multicolumn{2}{|l|}{10} \\
\hline & & & & & & & & & & & & & & & & & & & & \\
\hline (2) Brand name value & 0.581 & $* *$ & & & & & & & & & & & & & & & & & & \\
\hline (3) Unit performance & 0.333 & $* *$ & 0.335 & $* *$ & & & & & & & & & & & & & & & & \\
\hline (4) Franchisee satisfaction & 0.595 & $* *$ & 0.520 & $* *$ & 0.396 & $* *$ & & & & & & & & & & & & & & \\
\hline $\begin{array}{l}\text { (5) Intention to acquire } \\
\text { additional units }\end{array}$ & 0.344 & $* *$ & 0.290 & $* *$ & 0.276 & $* *$ & 0.341 & $* *$ & & & & & & & & & & & & \\
\hline (6) Overall conflict & -0.497 & $* *$ & -0.372 & $* *$ & -0.258 & $* *$ & 0.820 & $* *$ & -0.272 & $* *$ & & & & & & & & & & \\
\hline (7) Conflict on pricing & -0.354 & $* *$ & -0.279 & $* *$ & -0.168 & $* *$ & -0.584 & $* *$ & -0.149 & $* *$ & 0.602 & $* *$ & & & & & & & & \\
\hline $\begin{array}{l}\text { (8) Franchisor use of direct } \\
\text { pricing }\end{array}$ & 0.343 & $* *$ & 0.365 & $* *$ & 0.237 & $* *$ & 0.488 & $* *$ & 0.196 & $* *$ & -0.383 & $* *$ & -0.236 & $* *$ & & & & & & \\
\hline $\begin{array}{l}\text { (9) Franchisor/franchisee } \\
\text { cooperation in pricing }\end{array}$ & 0.371 & $* *$ & 0.285 & $* *$ & 0.182 & $* *$ & 0.615 & $* *$ & 0.292 & $* *$ & -0.513 & $* *$ & -0.373 & $* *$ & 0.534 & $* *$ & & & & \\
\hline $\begin{array}{l}\text { (10) Franchisor use of indirect } \\
\text { pricing }\end{array}$ & 0.056 & & 0.232 & $* *$ & 0.053 & & 0.089 & & 0.131 & $* *$ & -0.014 & & 0.081 & & 0.377 & $* *$ & 0.263 & $* *$ & & \\
\hline $\begin{array}{l}\text { (11) Franchisee allegiance to } \\
\text { franchisor pricing }\end{array}$ & 0.407 & $* *$ & 0.343 & $* *$ & 0.223 & $* *$ & 0.609 & $* *$ & 0.314 & $* *$ & -0.489 & $* *$ & -0.394 & $* *$ & 0.574 & $* *$ & 0.676 & $* *$ & 0.240 & $* *$ \\
\hline $\begin{array}{l}\text { (12) Franchisee confidence in } \\
\text { franchisor pricing }\end{array}$ & 0.343 & $* *$ & 0.258 & $* *$ & 0.252 & $* *$ & 0.566 & $* *$ & 0.275 & $* *$ & -0.490 & $* *$ & -0.427 & $* *$ & 0.304 & $* *$ & 0.507 & $* *$ & 0.051 & \\
\hline $\begin{array}{l}\text { (13) Franchisee autonomy in } \\
\text { pricing }\end{array}$ & -0.010 & & -0.080 & & 0.090 & & 0.069 & & -0.065 & & -0.071 & & -0.105 & $*$ & -0.106 & $*$ & 0.059 & & -0.227 & $* *$ \\
\hline $\begin{array}{l}\text { (14) Mutual communication on } \\
\text { pricing practices }\end{array}$ & 0.378 & $* *$ & 0.273 & $* *$ & 0.240 & $* *$ & 0.610 & $* *$ & 0.282 & $* *$ & -0.492 & $* *$ & -0.341 & $* *$ & 0.520 & $* *$ & 0.799 & $* *$ & 0.224 & $* *$ \\
\hline $\begin{array}{l}\text { (15) Mutual harmonization } \\
\text { efforts concerning pricing } \\
\text { practices }\end{array}$ & 0.397 & $* *$ & 0.287 & $* *$ & 0.217 & $* *$ & 0.680 & $* *$ & 0.277 & $* *$ & -0.609 & $* *$ & -0.524 & $* *$ & 0.394 & $* *$ & 0.692 & $* *$ & 0.169 & $* *$ \\
\hline $\begin{array}{l}\text { (16) Mutual understanding of } \\
\text { interests concerning pricing } \\
\text { practices }\end{array}$ & 0.401 & $* *$ & 0.338 & $* *$ & 0.199 & $* *$ & 0.651 & $* *$ & 0.314 & $* *$ & -0.518 & $* *$ & -0.407 & $* *$ & 0.519 & $* *$ & 0.645 & $* *$ & 0.187 & $* *$ \\
\hline (17) Chain size & 0.178 & $* *$ & 0.283 & $* *$ & 0.125 & $*$ & 0.099 & $*$ & 0.130 & $* *$ & -0.073 & & -0.006 & & 0.173 & $* *$ & 0.078 & & 0.244 & $* *$ \\
\hline (18) Chain age & 0.103 & $*$ & 0.317 & $* *$ & 0.116 & $*$ & 0.208 & $* *$ & -0.017 & & -0.189 & $* *$ & -0.111 & $*$ & 0.279 & $* *$ & 0.138 & $* *$ & 0.300 & $* *$ \\
\hline (19) Multi-unit ownership & 0.051 & & 0.147 & $* *$ & 0.105 & $*$ & 0.023 & & 0.157 & $* *$ & 0.001 & & -0.030 & & -0.020 & & 0.025 & & 0.012 & \\
\hline (20) Exclusive territory & 0.022 & & -0.060 & & 0.070 & & 0.046 & & 0.021 & & -0.067 & & -0.056 & & 0.026 & & 0.015 & & -0.170 & $* *$ \\
\hline (21) Environmental uncertainty & -0.119 & $*$ & -0.076 & & -0.332 & $* *$ & -0.174 & $* *$ & -0.128 & $* *$ & 0.121 & $*$ & 0.118 & $*$ & -0.044 & & -0.100 & $*$ & -0.040 & \\
\hline
\end{tabular}




\section{Table 1b: Correlations}

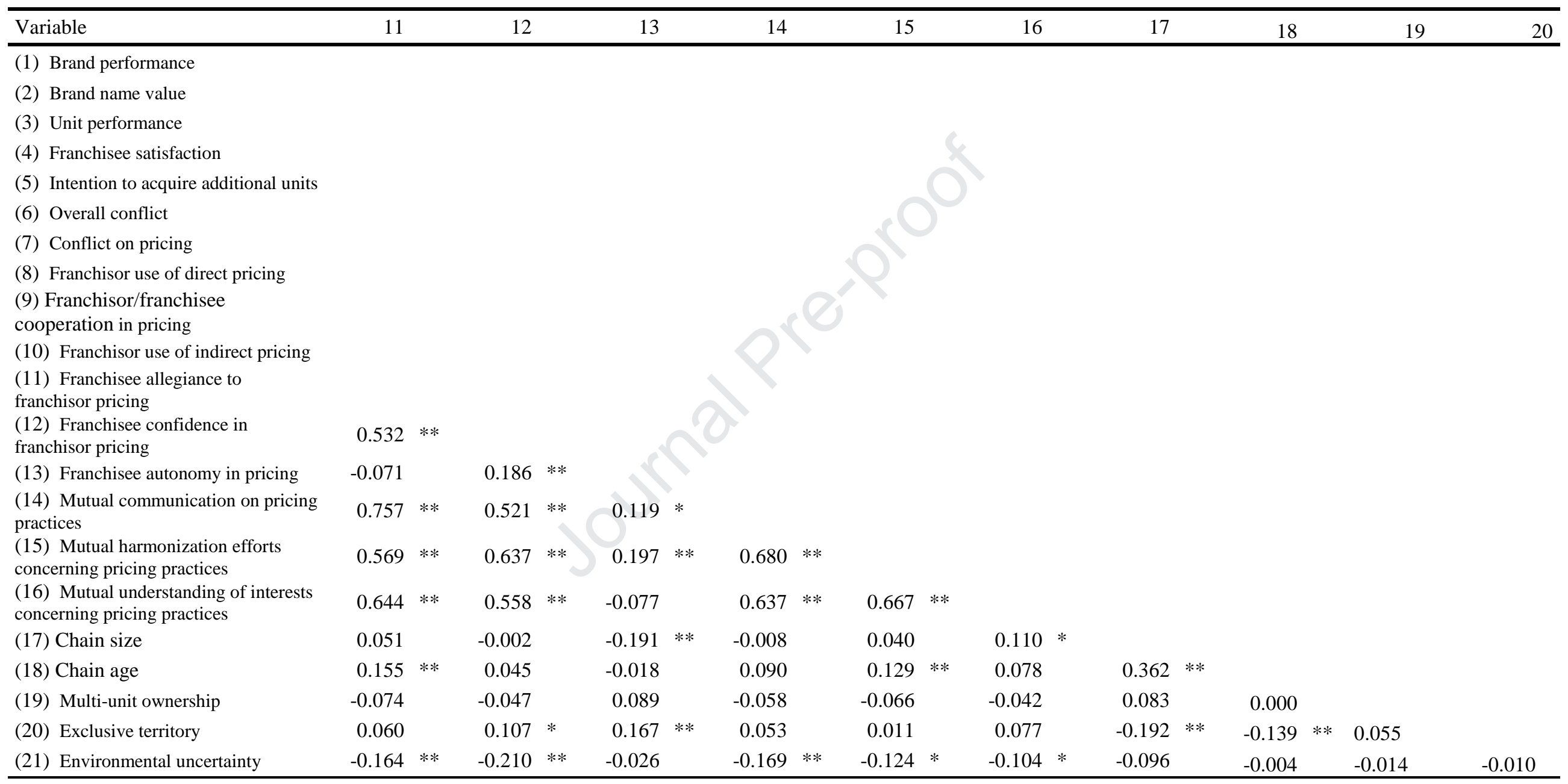

Significance levels (two-tailed)

$* * \mathrm{p}<0.01$

$* \mathrm{p}<0.05$ 
Table 2: Means and standard deviations

\begin{tabular}{|c|c|c|c|}
\hline & Variable & Mean & Std. deviation \\
\hline \multirow[t]{7}{*}{ Dependent variables } & (1) Brand performance & 3.4837 & 0.6437 \\
\hline & (2) Brand name value & 3.7592 & 1.0202 \\
\hline & (3) Unit performance & 2.8933 & 0.7962 \\
\hline & (4) Franchisee satisfaction & 3.5406 & 1.0047 \\
\hline & (5) Intention to acquire additional units & 2.3924 & 1.1756 \\
\hline & (6) Overall conflict & 1.9475 & 1.1372 \\
\hline & (7) Conflict on pricing & 1.9253 & 1.0542 \\
\hline \multicolumn{4}{|c|}{ Franchisor level - attitudes and practices } \\
\hline & (8) Franchisor use of direct pricing & 3.2931 & 1.0078 \\
\hline & $\begin{array}{l}\text { (9) Franchisor/franchisee } \\
\text { cooperationin pricing }\end{array}$ & 2.9146 & 1.0530 \\
\hline & (10) Franchisor use of indirect pricing & 2.5921 & 0.8324 \\
\hline \multicolumn{4}{|c|}{ Franchisee level-attitudes and practices } \\
\hline & $\begin{array}{l}\text { (11) Franchisee allegiance to franchisor } \\
\text { pricing }\end{array}$ & 3.2701 & 1.1972 \\
\hline & $\begin{array}{l}\text { (12) Franchisee confidence in franchisor } \\
\text { pricing }\end{array}$ & 3.5099 & 0.9059 \\
\hline & (13) Franchisee autonomy in pricing & 3.6913 & 1.2024 \\
\hline \multicolumn{4}{|c|}{ System level-relational governance } \\
\hline & $\begin{array}{l}\text { (14) Mutual communication on pricing } \\
\text { practices }\end{array}$ & 3.0074 & 1.1699 \\
\hline & $\begin{array}{l}\text { (15) Mutual harmonization efforts } \\
\text { concerning pricing practices }\end{array}$ & 3.3202 & 1.0287 \\
\hline & $\begin{array}{l}\text { (16) Mutual understanding of interests } \\
\text { concerning pricing practices }\end{array}$ & 3.4581 & 1.1181 \\
\hline \multicolumn{4}{|l|}{ Controls } \\
\hline & (17) Chain size & 178.05 & 169.954 \\
\hline & (18) Chain age & 4.19 & 0.971 \\
\hline & (19) Multi-unit ownership & 0.23 & 0.479 \\
\hline & (20) Exclusive territory & 0.78 & 0.412 \\
\hline & (21) Environmental uncertainty & 3.2177 & 0.67541 \\
\hline
\end{tabular}


Table 3: Structural equation modeling results

\begin{tabular}{|c|c|c|c|c|c|c|c|}
\hline \multirow[t]{2}{*}{ Perspectives } & \multicolumn{2}{|c|}{ Franchisor level outcomes } & \multicolumn{3}{|c|}{ Franchisee level outcomes } & \multicolumn{2}{|c|}{ System level outcomes } \\
\hline & $\begin{array}{l}\text { Brand } \\
\text { performance }\end{array}$ & $\begin{array}{l}\text { Brand name } \\
\text { value }\end{array}$ & $\begin{array}{l}\text { Unit } \\
\text { performance }\end{array}$ & $\begin{array}{l}\text { Franchisee } \\
\text { satisfaction }\end{array}$ & $\begin{array}{l}\text { Intention to } \\
\text { acquire add. } \\
\text { units }\end{array}$ & $\begin{array}{l}\text { Overall } \\
\text { conflict }\end{array}$ & $\begin{array}{l}\text { Conflict on } \\
\text { pricing }\end{array}$ \\
\hline \multicolumn{8}{|c|}{ Franchisor level - attitudes and practices } \\
\hline \multirow{2}{*}{$\begin{array}{l}\text { Franchisor use of direct } \\
\text { pricing }\end{array}$} & $0.091^{*}$ & $0.139 *$ & $0.142 * *$ & $0.135^{* * *}$ & -0.032 & $-0.125^{*}$ & -0.039 \\
\hline & $(0.036)$ & $(0.057)$ & $(0.047)$ & $(0.041)$ & $(0.070)$ & $(0.055)$ & $(0.056)$ \\
\hline \multirow{2}{*}{$\begin{array}{l}\text { Franchisor/franchise } \\
\text { e cooperationin } \\
\text { pricing }\end{array}$} & -0.014 & -0.094 & $-0.101 \dagger$ & 0.058 & 0.027 & -0.085 & -0.030 \\
\hline & $(0.048)$ & $(0.075)$ & $(0.061)$ & $(0.054)$ & $(0.092)$ & $(0.072)$ & $(0.073)$ \\
\hline \multirow{2}{*}{$\begin{array}{l}\text { Franchisor use of } \\
\text { indirect pricing }\end{array}$} & $-0.100^{* *}$ & 0.033 & -0.047 & $-0.187 * * *$ & 0.068 & $0.273^{* * *}$ & $0.285^{* * *}$ \\
\hline & $(0.036)$ & $(0.057)$ & $(0.046)$ & $(0.041)$ & $(0.070)$ & $(0.055)$ & $(0.055)$ \\
\hline
\end{tabular}

Franchisee level-attitudes and practices

\begin{tabular}{llllllll}
\hline $\begin{array}{l}\text { Franchisee allegiance } \\
\text { to franchisor pricing }\end{array}$ & $0.079^{*}$ & $0.111 \dagger$ & -0.004 & $0.101^{*}$ & $0.146 \dagger$ & -0.083 & $-0.183^{* *}$ \\
& $(0.040)$ & $(0.062)$ & $(0.051)$ & $(0.045)$ & $(0.076)$ & $(0.060)$ & $(0.061)$ \\
$\begin{array}{l}\text { Franchisee confidence } \\
\text { in franchisor pricing }\end{array}$ & 0.050 & 0.105 & $0.090 \dagger$ & $0.116^{*}$ & $0.134 \dagger$ & $-0.127^{*}$ & -0.100 \\
& $(0.042)$ & $(0.066)$ & $(0.054)$ & $(0.048)$ & $(0.081)$ & $(0.064)$ & $(0.064)$ \\
$\begin{array}{l}\text { Franchisee autonomy } \\
\text { in pricing }\end{array}$ & -0.022 & -0.041 & 0.033 & -0.016 & -0.076 & 0.052 & 0.016 \\
& $(0.026)$ & $(0.041)$ & $(0.033)$ & $(0.029)$ & $(0.050)$ & $(0.039)$ & $(0.040)$ \\
\hline
\end{tabular}

System level - relational governance

\begin{tabular}{|c|c|c|c|c|c|c|c|}
\hline $\begin{array}{l}\text { Mutual communication } \\
\text { on pricing practices }\end{array}$ & $\begin{array}{l}0.026 \\
(0.047)\end{array}$ & $\begin{array}{l}0.004 \\
(0.073)\end{array}$ & $\begin{array}{l}0.089 \\
(0.060)\end{array}$ & $\begin{array}{l}0.024 \\
(0.053)\end{array}$ & $\begin{array}{l}0.018 \\
(0.090)\end{array}$ & $\begin{array}{l}0.021 \\
(0.071)\end{array}$ & $\begin{array}{l}0.181^{*} \\
(0.072)\end{array}$ \\
\hline $\begin{array}{l}\text { Mutual harmonization } \\
\text { efforts concerning } \\
\text { pricing practices }\end{array}$ & $\begin{array}{l}0.114 * \\
(0.045)\end{array}$ & $\begin{array}{l}0.078 \\
(0.071)\end{array}$ & $\begin{array}{l}0.042 \\
(0.058)\end{array}$ & $\begin{array}{l}0.305 * * * \\
(0.051)\end{array}$ & $\begin{array}{l}0.089 \\
(0.087)\end{array}$ & $\begin{array}{l}-0.435 * * * \\
(0.069)\end{array}$ & $\begin{array}{l}-0.406^{* * *} \\
(0.069)\end{array}$ \\
\hline $\begin{array}{l}\text { Mutual understanding } \\
\text { of interests concerning } \\
\text { pricing practices }\end{array}$ & $\begin{array}{l}0.035 \\
(0.039)\end{array}$ & $\begin{array}{l}0.101 \dagger \\
(0.061)\end{array}$ & $\begin{array}{l}-0.006 \\
(0.050)\end{array}$ & $\begin{array}{l}0.172 * * * \\
(0.044)\end{array}$ & $\begin{array}{l}0.083 \\
(0.075)\end{array}$ & $\begin{array}{l}-0.068 \\
(0.059)\end{array}$ & $\begin{array}{l}-0.046 \\
(0.060)\end{array}$ \\
\hline
\end{tabular}

\begin{tabular}{|c|c|c|c|c|c|c|c|}
\hline \multicolumn{8}{|l|}{ Controls } \\
\hline \multirow{2}{*}{$\begin{array}{l}\text { Environmental } \\
\text { uncertainty }\end{array}$} & -0.028 & -0.001 & $-0.330 * * *$ & $-0.090 \dagger$ & -0.082 & 0.047 & 0.070 \\
\hline & $(0.041)$ & $(0.064)$ & $(0.052)$ & $(0.046)$ & $(0.078)$ & $(0.062)$ & $(0.062)$ \\
\hline \multirow{2}{*}{ Exclusive territory } & 0.001 & -0.083 & 0.092 & -0.014 & 0.030 & -0.088 & -0.007 \\
\hline & $(0.068)$ & $(0.107)$ & $(0.088)$ & $(0.077)$ & $(0.131)$ & $(0.103)$ & $(0.105)$ \\
\hline \multirow{2}{*}{ Multi-unit ownership } & $0.106 \dagger$ & $0.363 * * *$ & $0.184 *$ & $0.148 *$ & $0.434 * * *$ & -0.101 & $-0.116 \dagger$ \\
\hline & $(0.058)$ & $(0.090)$ & $(0.074)$ & $(0.065)$ & $(0.111)$ & $(0.087)$ & $(0.088)$ \\
\hline \multirow{2}{*}{ Chain age } & -0.006 & $0.192 * * *$ & 0.045 & $0.125 * * *$ & $-0.136 *$ & $-0.160 * * *$ & $-0.104^{*}$ \\
\hline & $(0.031)$ & $(0.048)$ & $(0.039)$ & $(0.035)$ & $(0.059)$ & $(0.046)$ & $(0.047)$ \\
\hline \multirow{2}{*}{ Chain size } & $0.001 * * *$ & $0.001 * *$ & $0.001 \dagger$ & 0.000 & $0.001 *$ & 0.000 & 0.000 \\
\hline & $(0.000)$ & $(0.000)$ & $(0.000)$ & $(0.000)$ & $(0.000)$ & $(0.000)$ & $(0.000)$ \\
\hline Fit statistics & $0.94 / 0.92 /$ & $0.94 / 0.92 /$ & $0.94 / 0.92 /$ & $0.95 / 0.93 /$ & $0.94 / 0.92 /$ & $0.94 / 0.93 /$ & $0.94 / 0.93 /$ \\
\hline CFI/NFI/IFI/RMSEA & $0.94 / 0.08$ & $0.94 / 0.08$ & $0.94 / 0.08$ & $0.95 / 0.08$ & $0.94 / 0.08$ & $0.95 / 0.08$ & $0.94 / 0.08$ \\
\hline
\end{tabular}

Significance levels (2-tailed), $* * * \mathrm{p}<0.001 ; * * \mathrm{p}<0.01 ;{ }^{*} \mathrm{p}<0.05 ; \uparrow \mathrm{p}<0.1$. Robust standard errors in parentheses. 


\section{Appendix 2: Figures 1-8}

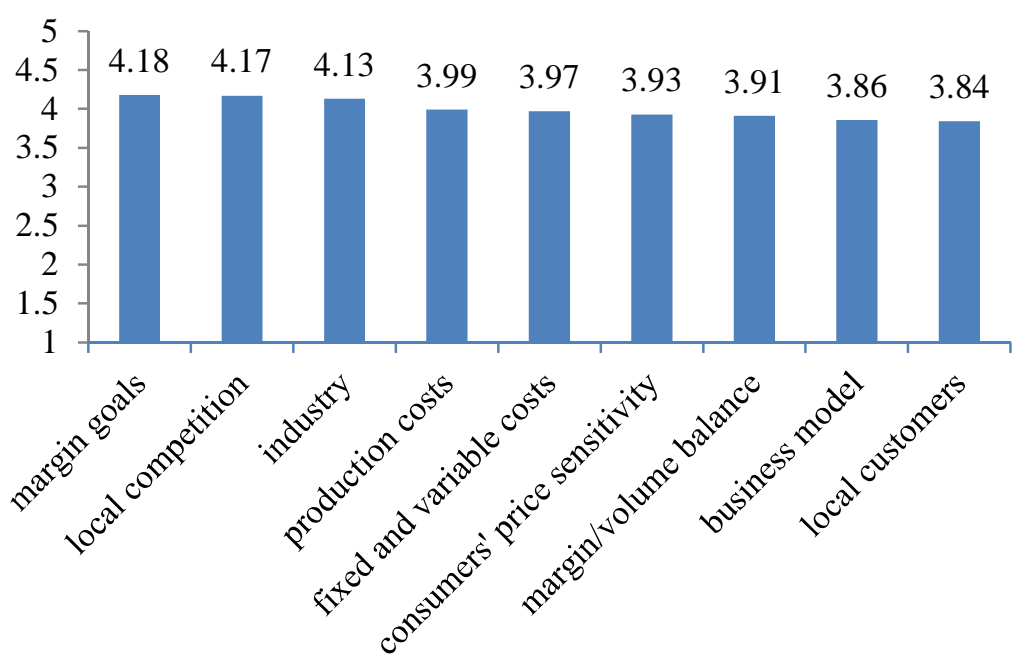

Figure 1: Relevance of criteria for price-setting as perceived by franchisees (1-5 scale).

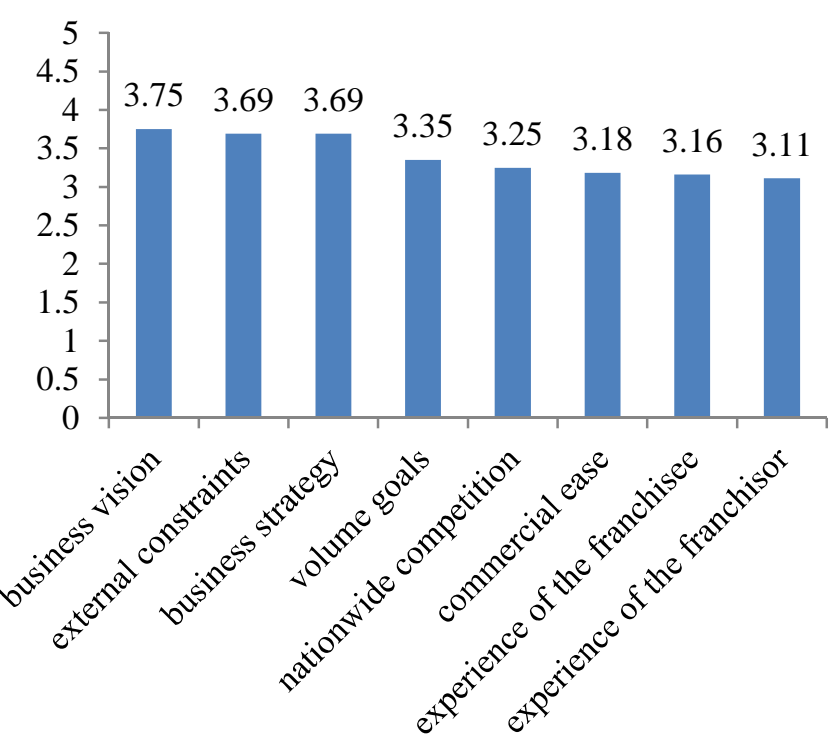

Figure 2: Relevance of criteria for price-setting (continued from Figure 2).

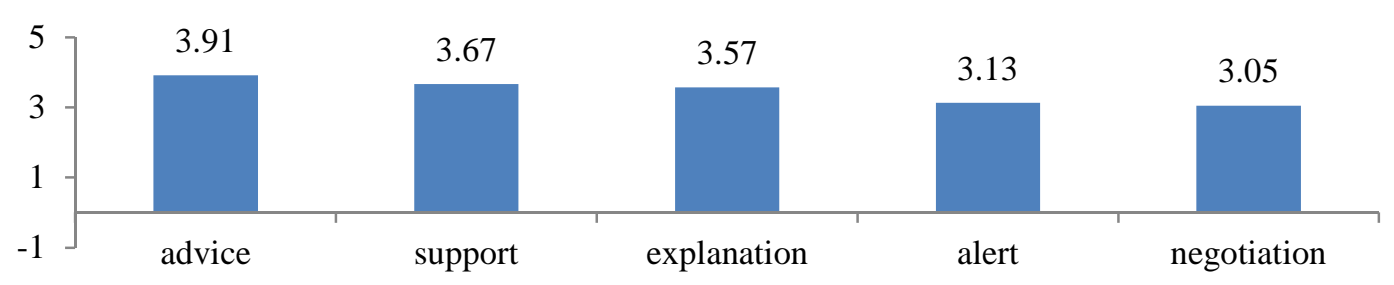

Figure 3: Role of the franchisor in price-setting as perceived by franchisees (1-5 scale). 


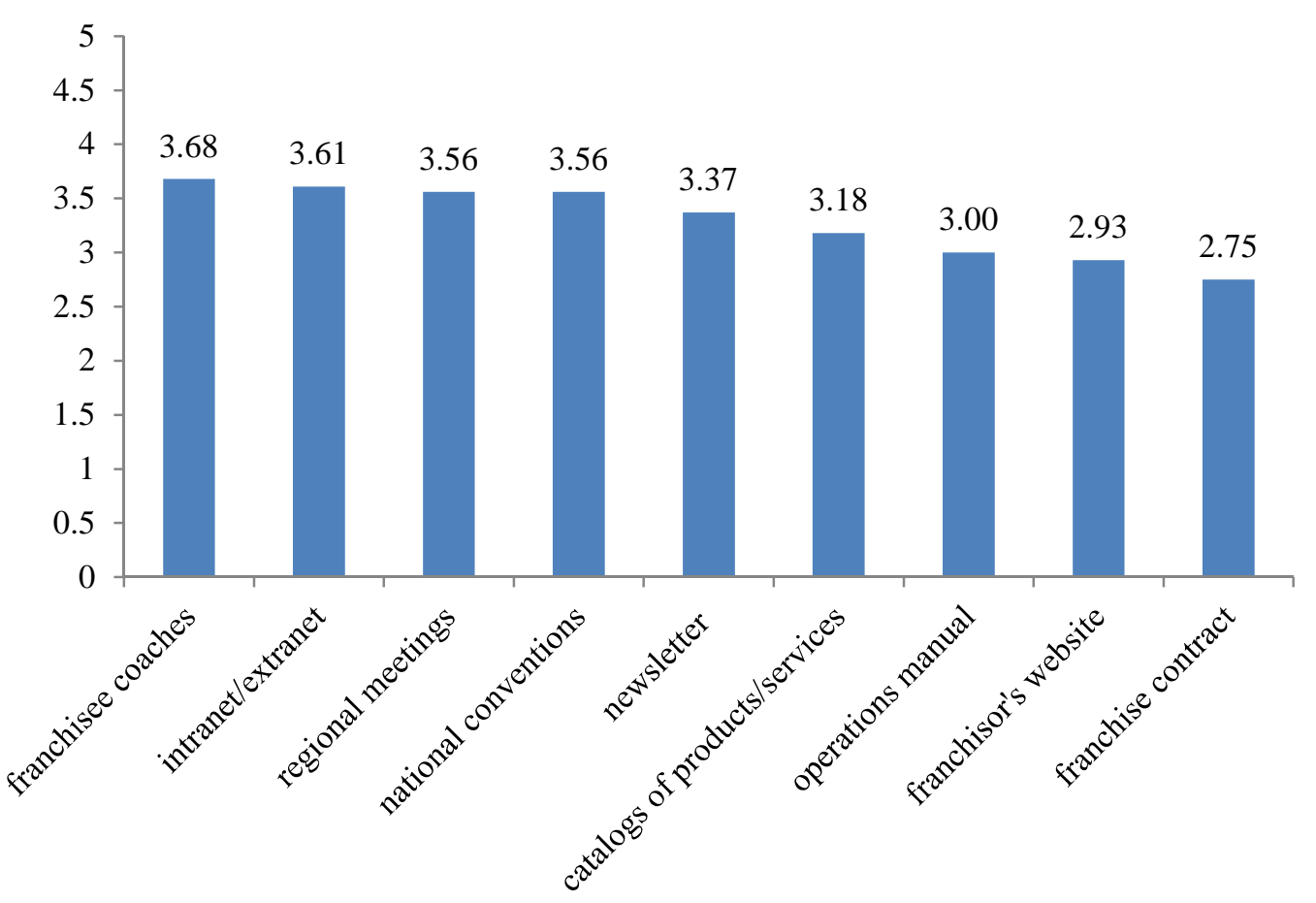

Figure 4: Sources of pricing information used by franchisees (1-5 scale).

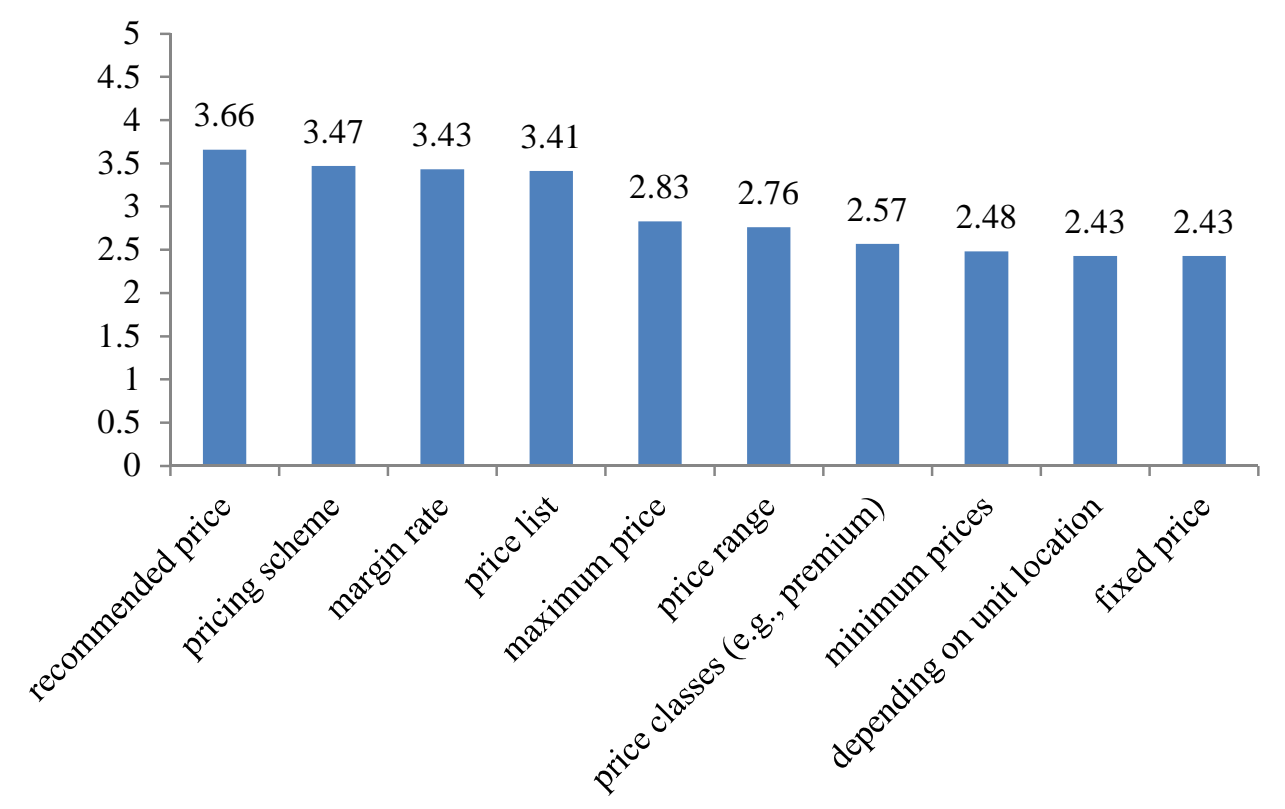

Figure 5: Franchisor explicit pricing directions as perceived by franchisees (1-5 scale). 


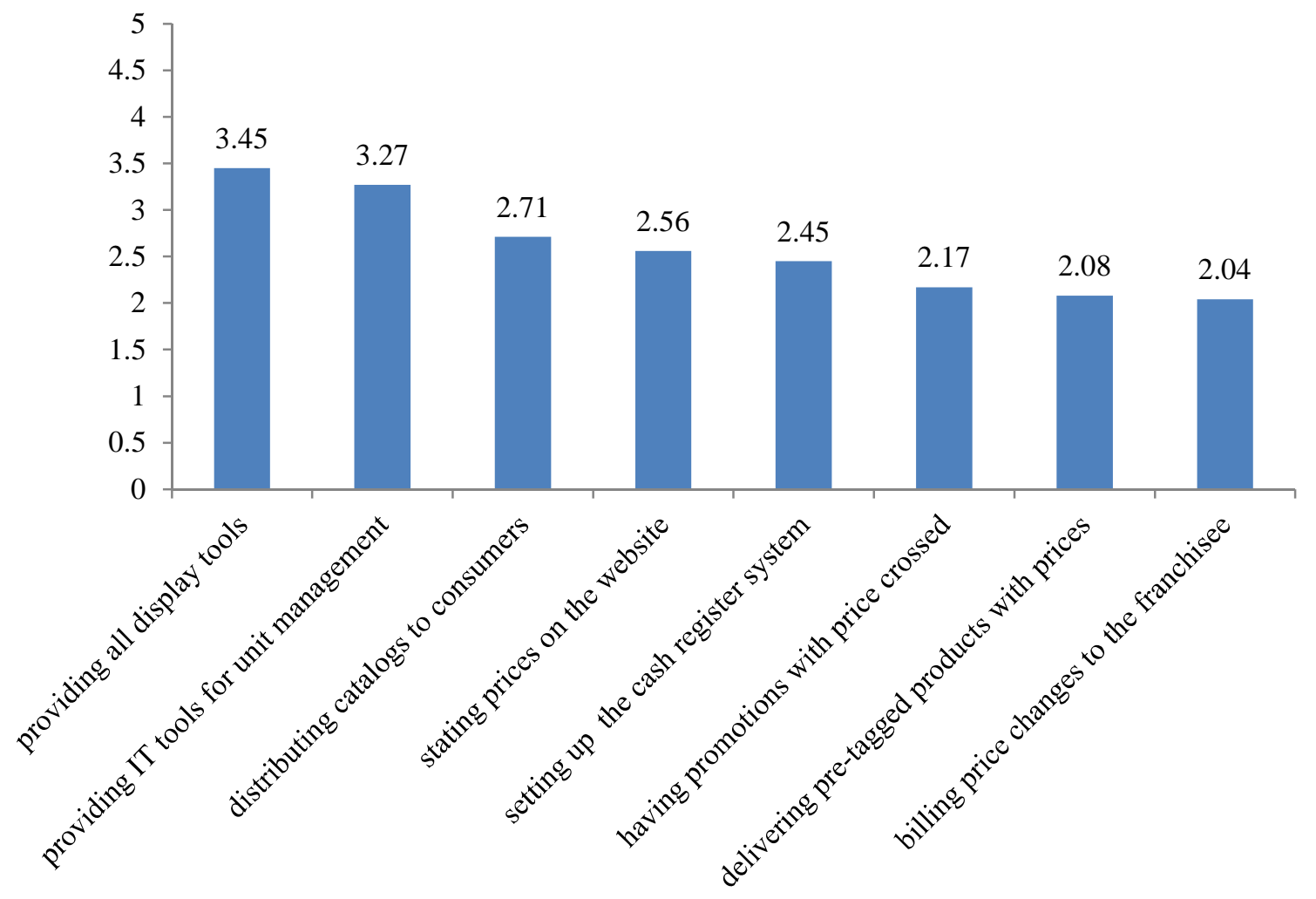

Figure 6: Franchisor implicit pricing directions as perceived by franchisees (1-5 scale).

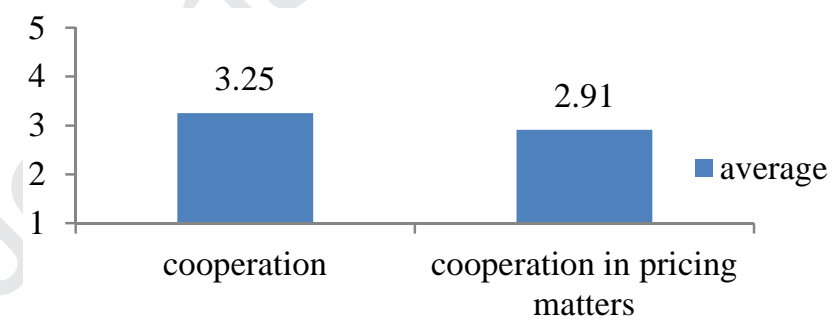

Figure 7: Intensity of franchisee-franchisor cooperation (1-5 scale).

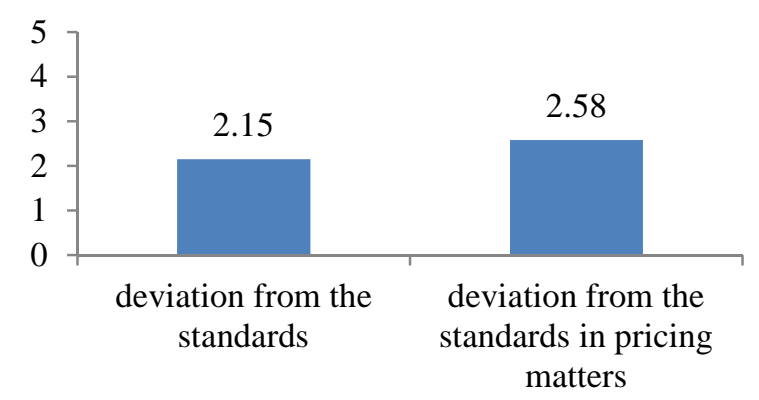

Figure 8: Franchisee deviation from franchisor standards (1-5 scale). 


\section{Appendix 3: Measures employed}

\begin{tabular}{|c|c|c|c|c|}
\hline Perspective & Construct & $\begin{array}{c}\text { Items/measures } \\
\text { (anchored with 5-point likert-type scales } 1=" I \text { strongly disagree" to } 5=\text { "I strongly agree", unless stated otherwise) }\end{array}$ & $\begin{array}{l}\text { Cronbach's } \\
\text { alpha }\end{array}$ & AVE \\
\hline \multirow{3}{*}{$\begin{array}{l}\text { Franchisor- } \\
\text { level }\end{array}$} & $\begin{array}{l}\text { Direct pricing } \\
\text { adapted from Meek } \text { et } \\
\text { al. (2011) }\end{array}$ & $\begin{array}{l}\text { (1) My franchisor informs me about pricing policy of the brand through, on-field consultants and other people from the headquarters } \\
\text { (2) My franchisor informs me about pricing policy of the brand through, the newsletter or the chain's newsletter } \\
\text { (3) My franchisor informs me about pricing policy of the brand through, the catalogs of products and/or services } \\
\text { (4) My franchisor informs me about pricing policy of the brand through, the chain's intranet or extranet website } \\
\text { (5) My franchisor informs me about pricing policy of the brand through, the institutional website (the franchisor website) } \\
\text { (6) My franchisor informs me about pricing policy of the brand through, regional meetings } \\
\text { (7) My franchisor informs me about pricing policy of the brand through, national conventions } \\
\text { (8) My franchisor informs me about pricing policy of the brand through, the franchise contract } \\
\text { (9) My franchisor informs me about pricing policy of the brand through, the operations manual (the franchisor's "bible") }\end{array}$ & 0.881 & 0.587 \\
\hline & $\begin{array}{l}\text { Franchisor/franchisee } \\
\text { cooperation in pricing } \\
\text { practices } \\
\text { adapted from Cochet et } \\
\text { al. }(2008)\end{array}$ & $\begin{array}{l}\text { (1) When making decisions which concern resale price setting, my franchisor takes into account my opinion. } \\
\text { (2) My franchisor asks me for participation in his long-term planning process regarding resale prices. } \\
\text { (3) I receive information on resale prices from my franchisor on time. }\end{array}$ & 0.813 & 0.581 \\
\hline & $\begin{array}{l}\text { Indirect pricing } \\
\text { Adapted from } \\
\text { information gained } \\
\text { through interviewing } \\
\text { franchisees in the pre- } \\
\text { study }\end{array}$ & $\begin{array}{l}\text { (1) In my chain, there are many special offers with strikethrough prices. } \\
\text { (2) My franchisor provides me every display and promotion means to be used in my unit } \\
\text { (3) When I want to modify the prices on the franchisor's means of communication, the franchisor charges me the adjustment. } \\
\text { (4) My franchisor delivers products which are already labelled. } \\
\text { (5) My franchisor publishes catalogs (or menus, etc.) on which the resale prices are specified. } \\
\text { (6) The cash register's system is automatically configured by the headquarters' team. } \\
\text { (7) The resale prices of the products/services that I sell in my franchised unit are available to my customers on the franchisor's website. } \\
\text { (8) My franchise chain provides me with management IT tools which enable me to establish prices effectively. }\end{array}$ & 0.682 & 0.559 \\
\hline \multirow{3}{*}{$\begin{array}{l}\text { Franchisee- } \\
\text { level }\end{array}$} & $\begin{array}{l}\text { Allegiance to pricing } \\
\text { practices } \\
\text { adapted from Williams } \\
(2007)\end{array}$ & $\begin{array}{l}\text { (1) My franchisor provides valuable information on resale prices for my business. } \\
\text { (2) I learn a lot from my franchisor in terms of resale price setting. } \\
\text { (3) My franchisor provides examples of ways to set resale prices. }\end{array}$ & 0.861 & 0.586 \\
\hline & $\begin{array}{l}\text { Confidence in pricing } \\
\text { practices } \\
\text { adapted from Cochet } e t \\
\text { al. (2008) }\end{array}$ & $\begin{array}{l}\text { (1) My franchisor does not exploit my dependency in terms of resale prices. } \\
\text { (2) My franchisor's trust in me is high when dealing with resale price setting. } \\
\text { (3) I can follow the recommendations of my franchisor on resale prices without any hesitation. }\end{array}$ & 0.772 & 0.552 \\
\hline & $\begin{array}{l}\text { Autonomy in pricing } \\
\text { adapted from Blut } \text { et al. } \\
\text { (2011) }\end{array}$ & $\begin{array}{l}\text { (1) As franchisee, and in terms of setting resale prices, I feel like an independent entrepreneur. } \\
\text { (2) Concerning resale prices, I have total freedom to establish my franchise's operational policies and procedures. } \\
\text { (3) Regarding resale prices, I rarely depend on anyone else to get things done. }\end{array}$ & 0.780 & 0.555 \\
\hline
\end{tabular}




\begin{tabular}{|c|c|c|c|c|}
\hline \multirow[b]{3}{*}{ System-level } & $\begin{array}{l}\text { Communication on } \\
\text { pricing practices } \\
\text { adapted from Chiou, } \\
\text { Hsieh and Yang (2004) }\end{array}$ & $\begin{array}{l}\text { (1) Regarding resale prices, my franchisor emphasizes two-way communication. } \\
\text { (2) The information on resale prices provided by my franchisor is very helpful in solving my store's problems. } \\
\text { (3) If I ask any questions and suggestions concerning resale prices, my franchisor will handle the questions and suggestions immediately. }\end{array}$ & 0.875 & 0.625 \\
\hline & $\begin{array}{l}\text { Harmonization efforts } \\
\text { concerning pricing } \\
\text { practices } \\
\text { adapted from Cochet et } \\
\text { al. }(2008)\end{array}$ & $\begin{array}{l}\text { (1) My franchisor understands my problems and concerns in terms of resale prices. } \\
\text { (2) My franchisor seeks compromises to accommodate conflicts when dealing with resale prices. } \\
\text { (3) Disputes about resale prices are not typical for the relationship between me and my franchisor. }\end{array}$ & 0.888 & 0.601 \\
\hline & $\begin{array}{l}\text { Mutual understanding } \\
\text { concerning interests in } \\
\text { pricing practices } \\
\text { adapted from Tikoo } \\
(2005) \\
\end{array}$ & $\begin{array}{l}\text { (1) My franchisor provides a clear picture of the anticipated positive impact on my business adopting a recommended resale pricing scheme } \\
\text { will have. } \\
\text { (2) My franchisor makes it explicit, when making a suggestion about resale price setting that it is intended for the good of my operation. } \\
\text { (3) My franchisor states that by following its recommendations on resale prices, my business would benefit. }\end{array}$ & 0.858 & 0.621 \\
\hline \multirow{6}{*}{ Outcomes } & $\begin{array}{l}\text { Franchisor-level, } \\
\text { Chain performance } \\
\text { adapted from Blut et al. } \\
\text { (2011) }\end{array}$ & $\begin{array}{l}\text { (1) Over the last three years and compared to our competitors, the performance of the chain in terms of sales is.... } \\
\text { (2) Over the last three years and compared to our competitors, the performance of the chain in terms of profitability is.... } \\
\text { (3) Over the last three years and compared to our competitors, the performance of the chain in terms of market share is .... } \\
\text { (4) Over the last three years and compared to our competitors, the performance of the chain in terms of product and service quality is .... } \\
\text { (5) Over the last three years and compared to our competitors, the performance of the chain in terms of customer satisfaction is .... }\end{array}$ & 0.866 & 0.605 \\
\hline & $\begin{array}{l}\text { Franchisor-level, } \\
\text { Brand name value } \\
\text { adapted from Hussain } \\
\text { et al. }(2013) \\
\end{array}$ & $\begin{array}{l}\text { (1) Compared with our competitors, our brand recognition is strong. } \\
\text { (2) Compared with our competitors, our chain has a good reputation for quality and service. } \\
\text { (3) Oour brand name is one of our most precious assets. } \\
\text { (4) Compared with our competitors, our chain is well respected. }\end{array}$ & 0.926 & 0.637 \\
\hline & $\begin{array}{l}\text { Franchisee-level, unit } \\
\text { performance } \\
\text { adapted from Mignonac } \\
\text { et al. }(2015)\end{array}$ & $\begin{array}{l}\text { (1) Compared to other franchisees in this chain, my outlet(s) is/are, } \\
\text { (2) Based on the business objectives I set myself, the performance of my outlet is, } \\
\text { (3) Based on the franchisor's forecasts, the performance of my outlet(s) is, } \\
\text { [(1) poor, (2) below expectations, (3) average, (4) above expectations, (5) outstanding] }\end{array}$ & 0.862 & 0.569 \\
\hline & $\begin{array}{l}\text { Franchisee-level, } \\
\text { satisfaction } \\
\text { adapted from Davies et } \\
\text { al. }(2011)\end{array}$ & $\begin{array}{l}\text { (1) My relationship with the franchisor has been an unhappy one. [strongly disagree-strongly agree] } \\
\text { (2) Generally I am very satisfied with my overall relationship with the franchisor. [strongly disagree-strongly agree] } \\
\text { (3) I am very pleased with my working relationship with the franchisor. [strongly disagree-strongly agree] } \\
\text { (4) My association with the franchisor has been a highly successful one. [strongly disagree-strongly agree] } \\
\text { (5) If I had to give the franchisor a performance appraisal for the past year, it would be [poor-outstanding]. } \\
\text { (6) Taking different factors into account, the franchisor's performance has been [bad-excellent]. }\end{array}$ & 0.615 & 0.629 \\
\hline & $\begin{array}{l}\text { Franchisee-level, } \\
\text { intention to acquire } \\
\text { additional units } \\
\text { adapted from Mignonac } \\
\text { et al. }(2015) \\
\end{array}$ & $\begin{array}{l}\text { (1) I intend to own one or several additional units of this franchise organization in the next two years. } \\
\text { (2) Within the next six months, I intend to acquire an additional unit of this franchise organization. } \\
\text { (3) I don't plan to own additional units of this franchise organization (reverse scored). }\end{array}$ & 0.816 & 0.583 \\
\hline & $\begin{array}{l}\text { System level, overall } \\
\text { conflict } \\
\text { adapted from Davies et } \\
\text { al. (2011) }\end{array}$ & $\begin{array}{l}\text { (1) My relationship with the franchisor can be best described as tense. } \\
\text { (2) Tthe franchisor and I have significant disagreements in our working relationship. } \\
\text { (3) The franchisor and I frequently clash on issues relating to how I should conduct my business. }\end{array}$ & 0.935 & 0.651 \\
\hline
\end{tabular}




\begin{tabular}{|c|c|c|c|c|}
\hline & $\begin{array}{l}\text { System-level } \\
\text { conflict on pricing } \\
\text { practices } \\
\text { adapted from Davies et } \\
\text { al. }(2011) \\
\end{array}$ & $\begin{array}{l}\text { (1) My relationship with the franchisor can be best described as tense when dealing with resale prices. } \\
\text { (2) The franchisor and I have significant disagreements in our working relationship regarding resale prices. } \\
\text { (3) The franchisor and I frequently clash on issues relating to how I should conduct my business in terms of resale prices. }\end{array}$ & 0.875 & 0.569 \\
\hline \multirow{5}{*}{$\begin{array}{l}\text { Control } \\
\text { variables }\end{array}$} & Chain size & The total number of units within my chain is... (\#) & \multicolumn{2}{|c|}{ Tally measure } \\
\hline & Chain age & $\begin{array}{l}\text { My chain has been a franchised chain since, } \\
\text { a) less than } 3 \text { years (1) } \\
\text { b) } 3 \text { to } 5 \text { years ( } 2 \text { ) } \\
\text { c) } 5 \text { to } 10 \text { years ( } 3 \text { ) } \\
\text { d) } 10 \text { to } 20 \text { years ( } 4 \text { ) } \\
\text { e) more than } 20 \text { years (5) }\end{array}$ & \multicolumn{2}{|c|}{ Tally measure } \\
\hline & Multi-unit ownership & $\begin{array}{l}\text { I am managing... } \\
\text { a) a single unit in this chain (0) } \\
\text { b) two or several units in this chain (1) } \\
\text { c) two or several units in this chain and in (an) other chain(s) (2) }\end{array}$ & \multicolumn{2}{|c|}{ Tally measure } \\
\hline & $\begin{array}{l}\text { Provision of exclusive } \\
\text { territory }\end{array}$ & My franchise contract is containing a territorial clause that is beneficial for me (0-no, 1 -yes) & \multicolumn{2}{|c|}{ Tally measure } \\
\hline & $\begin{array}{l}\text { Environmental } \\
\text { uncertainty } \\
\text { adapted from Heide and } \\
\text { John (1988) }\end{array}$ & $\begin{array}{l}\text { (1) In my sales territory, the market is very complex. } \\
\text { (2) In my sales territory, market shares are stable. } \\
\text { (3) In my sales territory, it is easy to monitor trends. } \\
\text { (4) In my sales territory, sales forecasts are quite accurate. } \\
\text { (5) In my sales territory, there are many new competitors. }\end{array}$ & 0.632 & 0.486 \\
\hline
\end{tabular}

